\title{
The extreme drought of 1842 in Europe as described by both documentary data and instrumental measurements
}

\author{
Rudolf Brázdil $^{1}$, Gaston R. Demarée ${ }^{3}$, Andrea Kiss ${ }^{4,5}$, Petr Dobrovolný ${ }^{1}$, Kateřina Chromá ${ }^{2}$, Miroslav Trnka ${ }^{2,6}$, \\ Lukáš Dolák $^{1}$, Ladislava Řezníčková ${ }^{1,2}$, Pavel Zahradníček ${ }^{2,7}$, Danuta Limanowka ${ }^{8}$, and Sylvie Jourdain ${ }^{9}$ \\ ${ }^{1}$ Institute of Geography, Masaryk University, Brno, Czech Republic \\ ${ }^{2}$ Global Change Research Institute, Czech Academy of Sciences, Brno, Czech Republic \\ ${ }^{3}$ Royal Meteorological Institute of Belgium, Brussels, Belgium \\ ${ }^{4}$ Institute for Hydraulic Engineering and Water Resources Management, Vienna University of Technology, Vienna, Austria \\ ${ }^{5}$ Department of Historical Auxiliary Sciences, Institute of History, University of Szeged, Hungary \\ ${ }^{6}$ Department of Agrosystems and Bioclimatology, Mendel University in Brno, Brno, Czech Republic \\ ${ }^{7}$ Czech Hydrometeorological Institute, Brno, Czech Republic \\ ${ }^{8}$ Rydla 17, Kraków, Poland \\ ${ }^{9}$ Météo-France, Direction de la Climatologie et des Services Climatiques, Toulouse France
}

Correspondence: Rudolf Brázdil (brazdil@sci.muni.cz)

Received: 24 June 2019 - Discussion started: 26 June 2019

Revised: 31 August 2019 - Accepted: 12 September 2019 - Published: 17 October 2019

\begin{abstract}
Extreme droughts are weather phenomena of considerable importance, involving significant environmental and societal impacts. While those that have occurred in the comparatively recent period of instrumental measurement are identified and dated on the basis of systematic, machinestandardized meteorological and hydrological observations, droughts that took place in the pre-instrumental period are usually described only through the medium of documentary evidence. The extreme drought of 1842 in Europe presents a case in which information from documentary data can be combined with systematic instrumental observations. Seasonal, gridded European precipitation totals are used herein to describe general DJF, MAM, and JJA precipitation patterns. Annual variations in monthly temperatures and precipitation at individual stations are expressed with respect to a 1961-1990 reference period, supplemented by calculation of selected drought indices (Standardized Precipitation Index, SPI; Standardized Precipitation Evapotranspiration Index, SPEI; and Palmer Z index). The mean circulation patterns during the driest months are elucidated by means of sea-level pressure (SLP) maps, the North Atlantic Oscillation Index (NAOI), and the Central European Zonal Index (CEZI). Generally drier patterns in 1842 prevailed in January-February and at various intensities between April
\end{abstract}

and August. The driest patterns in 1842 occurred in a broad zonal belt extending from France to eastern central Europe. A range of documentary data is used to describe the peculiarities of agricultural, hydrological, and socio-economic droughts, with particular attention to environmental and societal impacts and human responses to them. Although overall grain yields were not very strongly influenced, a particularly bad hay harvest, no aftermath (hay from a second cut), and low potato yields led to severe problems, especially for those who raised cattle. Finally, the 1842 drought is discussed in terms of long-term drought variability, European tree-ringbased scPDSI (self-calibrated Palmer Drought Severity Index) reconstruction, and the broader context of societal impacts.

\section{Introduction}

Dry events, generally caused by reductions in precipitation totals compared to normal climatic conditions in a given area (meteorological drought), do not usually have such immediate and dramatic consequences (e.g. immediate loss of human lives, material damage) as might result from other hydrometeorological extremes - torrential rain, hailstorms, 
windstorms, floods, etc. The impacts of droughts appear over time, with some delay in the case of meteorological drought and progressively in agriculture (agricultural drought), water resources (hydrological and underground water drought), and society (socio-economic drought) (Heim, 2002; Mishra and Singh, 2010; Wilhite and Pulwarty, 2018). The anthropogenic activities at the origins of certain droughts should not be omitted (Van Loon et al., 2016a, b).

Particular attention to individual extraordinary drought events, based on the use of instrumental meteorological and hydrological data, is reflected in the considerable numbers of papers published in recent years (e.g. Fink et al., 2004; Shmakin et al., 2013; Hoerling et al., 2014; Spinoni et al., 2015; Zahradníček et al., 2015; Kogan and Guo, 2016; Laaha et al., 2017; Uhe et al., 2018). Contributions combining instrumental measurements with documentary data in the analysis of such events are less frequent (e.g. Dodds et al., 2009; Brázdil et al., 2016). Studies based exclusively upon documentary data tend to be those analysing severe drought events in the pre-instrumental period, for example, in Europe (Wetter et al., 2014; Kiss and Nikolić, 2015; Roggenkamp and Herget, 2015; Kiss, 2017, 2019; Pfister, 2018; Camenisch et al., 2019) or in other parts of the world (e.g. Hao et al., 2010; Zhang and Liang, 2010). Droughts in the pre-instrumental period may also be based on other types of proxies, particularly tree rings (see mainly PAGES Hydro2k Consortium, 2017, for an overview).

However, there are only few historical droughts that might lead to such an immediate response as that elicited by the 1842 drought. In particular, as early as 1 October 1842, Moritz Beyer (1807-1854), professor of agriculture at the Collegium Carolinum in Braunschweig, Germany, wrote of it in the preface to Futternoth- und Hülfsbuch ("The Book of Help in Forage Shortage"), motivated by the way in which the recent extreme drought had resulted in a critical lack of forage for livestock. He gave an overview of corresponding effects in many central European countries, and beyond, as well as recommendations as to how to mitigate negative effects (Beyer, 1843). The annual report of the I. R. PatrioticEconomic Society in Bohemia, in an evaluation of the agricultural conditions for 1842 mentioned that the adverse consequences of extraordinary atmospheric patterns in individual parts of agriculture will remain appreciable [for a] long [time]" (Neue Schriften, 1845, p. 216). The extraordinary drought of 1842 was reported in several papers: for example, for south-eastern Poland and north-western Ukraine (former Galicia; Szewczuk, 1939), Polish Silesia (Inglot, 1968), the Czech Lands (Munzar, 2004; Brázdil and Trnka, 2015; Brázdil et al., 2019a), and for the north-eastern part of the Greater Alpine Region (van der Schrier et al., 2007).

Developing upon the above, the current paper presents a comprehensive spatio-temporal analysis of the 1842 drought at a European scale (apart from the Mediterranean), based on the use of documentary evidence and systematic meteorological and hydrological observations that facilitate description of various aspects of this event. Section 2 characterizes the basic sources of documentary data, instrumental measurements, and other types of data used. The methodology of the paper is described in Sect. 3. The results in Sect. 4 concentrate on the spatio-temporal aspects of the 1842 drought, the synoptic and circulation patterns leading to it, and human impacts and responses. The longer-term context of this drought and its reflection in tree rings and phenophases, as well as the broader context of its impacts, are presented in Sect. 5. The final section contains some concluding remarks.

\section{Data}

\subsection{Documentary data}

Information concerning the 1842 drought may be derived from a range of documentary sources available from a number of European countries (see Fig. S1 in the Supplement), as indicated below:

i. Narrative sources (chronicles, "books of memory", diaries). Narrative sources usually report the occurrence or lack of precipitation and describe drought impacts for individual events on a broad scale. For example, the year 1842 appears in a chronicle kept in the bible of the Pitas family from Bohdašín (Bohemia) (Robek, 1976, p. 48): "It was such a dry year that from the month of April until the month of December only three light rains occurred, such that roots did not get wet. By the Will of God, the rye still recovered, but spring crops were so sparse that people had to pluck them in many places. The worst [situation] was for the cattle, because neither fodder nor clover grew on grazing land, and the grasslands were so dried out that they turned red, as if burnt by fire. Wells and brooks dried out and [matters were] so bad for milling that people had to carry [grain] several miles to mills with higher water." In a diary kept by Doeke Wijgers Hellema (1766-1856), a teacher in Wirdum (Friesland, the Netherlands), one reads " $22 \mathrm{Au}$ gust 1842, although not as dry and warm as before, [it] is still just as dry, even today. Although the sky was somewhat overcast last night, there is now almost clear air once more in the morning. The earth thirsts for water. Some lands here, perhaps more so elsewhere, are as dry as mid-winter. In addition, most ditches are empty, and farmers can hardly provide their animals with drinking water." (Archival source AS2, p. 86).

ii. Weather diaries and related weather observations. Certain people of education - county or state officials such as medical officers, town or district physicians, doctors, and priests - wrote monthly weather reports based on their weather diaries (sometimes with temperature and/or pressure measurements) as parts of the reports of illnesses they submitted to administrative bodies (Réthly, 1999). These departments, responsible for 
health issues, often required such information in order to prevent, monitor, and limit the proliferation of diseases (e.g. Berde, 1847). For example, the weather diary kept by Mihály Király, a subnotary of the Evangelical Church in Agârbiciu, central Transylvania (Romania), contains the following direct comments on droughts (Réthly, 1999, pp. 781-784). [24 April]: "silent, cloudy weather in the morning, and then strong, dry, cold wind. The vegetation is hampered and animals suffer as there is neither hay nor grass to feed them."; [13-15 August]: "continuous great heat, mostly windy days, very cool nights and mornings. Horrifying drought and huge [quantities of] dust; vegetation and harvest hampered in all senses"; [15 September]: "enormous thunderstorm at dawn, which eased the sweltering ground in this extraordinary three-month drought, which [in this area] stands almost without precedent, and gave new life to everything." Similar types of reports were also required from (hydro)engineers with respect to the weather and the daily water levels of particularly problematic rivers (e.g. see the Tisza; AS1).

iii. Newspapers. Newspapers contain information that covers droughts, especially when impacts on the environment and society are very severe. In particular, they report on the dry state of the soil and the lack of available water, the harvests of various crops, the prices of agricultural products and foodstuffs, the outbreaks of fires, etc. For example, on 7 June 1842 the French Journal des Débats politique et littéraire reported (p. 2) on the danger of a bad harvest due to heavy drought: "We read in the Précurseur de l'Ouest [at Angers] for 4 June: We have received sad information on the state of the countryside and the future of the crops from all points of the department of Maine-et-Loire. Hay, wheat, grain, and plants of all kinds have suffered considerably from the drought. The meadows will give little or no grass; the wheat is already yellowing before reaching its ordinary growth; oats are puny and short; the flax has aborted and will give only seed. Hemp, newly sown, will be in great danger." For Tápiószentmiklós in northwestern Hungary, Nemzeti Újság (10 September 1842, p. 291) described the situation in August 1842: "Complaints about the harvest and drought of the current year. The winter crops gave 2.5 seeds on average, the oats 2 , and the barley 3-4 seeds. We will perhaps have potatoes: there might have been ample fruiting, but [the foliage became] burnt. The pasture is narrow [i.e. bad]. There are only two wells in this huge area, but even there [i.e. near them], there is only little water. There will probably be wine." Reports from places other than the area or country of publication very often appear in newspapers. For example, a report relating to Wrocław (Poland) appears on 23 August in the Austrian Wiener Zeitung (28 August 1842, p. 1770): "Since 1811 no year has approached [this] one in terms of dryness [1842], [a fact that] is at least valid for our province. Although the year 1834 was almost drier than the current [year] for the eastern countries of Europe, we did not suffer so much from rain deficiency, and therefore we had no such paucity of fodder as in this year. Considerable shortage holds sway over many economies already, and it will intensify steadily until next spring [1843]."

iv. Epigraphic evidence. Low water levels on rivers following drought episodes may be recorded as marks for the corresponding year on "hunger stones" (also known as "dearth stones"), names that reflect failures of harvests and consequent increases in food prices, together with hunger, deprivation, and poverty. They are well known, for example, in the Czech Lands (Brázdil et al., 2013), Germany, Hungary (Palotay et al., 2012), and Switzerland (Pfister et al., 2006), but signs of the 1842 drought appear only on the river Elbe at Děčín in Bohemia (Fig. 1) and Magdeburg and Dresden in Germany (Elleder, 2016).

v. Society reports. A number of scientific and economic societies were interested in weather patterns with respect to their effects on agriculture, horticulture and forestry, even organizing their own meteorological observations. For example, the Société nationale d'horticulture de Paris in France published the results of meteorological observations made by HenriAntoine Jacques, horticulturist to the Duc d'Orléans, referring to the period between 1832 and 1850 in Neuilly-sur-Seine Château de Villiers (Société nationale d'horticulture de Paris, 1842). Two remarks made in the context of his instrumental measurements reflect the drought of 1842: "drought is extreme this year; vegetables are scarce and expensive. The tree nurseries are affected by this terrible drought and the trees are growing poorly." (July 1842, p. 137); "Finally, after 5 months of terrible drought, rain that fell in early September did a world of good" (September 1842, p. 223). In Bohemia, the I. R. Patriotic-Economic Society, as well as organizing and publishing results of meteorological and phenological observations from its own network of stations (Brázdil et al., 2011; Bělínová and Brázdil, 2012), reported annually on the general state of agriculture and forestry. For 1842 bad yields of agricultural crops in Bohemia and their consequences were evaluated as follows (Neue Schriften, 1845, pp. 218-219): "The harvest started earlier than usual everywhere; yields were, for the greater part, particularly of rye, below average; for barley and oats bad; and only for wheat a little better. Potatoes gave a bad harvest in almost the entire country [... nearly everywhere the harvest of hay [in 1842] was less than that of 1841 by a third or a half. The aftermath [hay from a second cut] failed totally nearly everywhere. [...] Reduction of cattle numbers by a third 


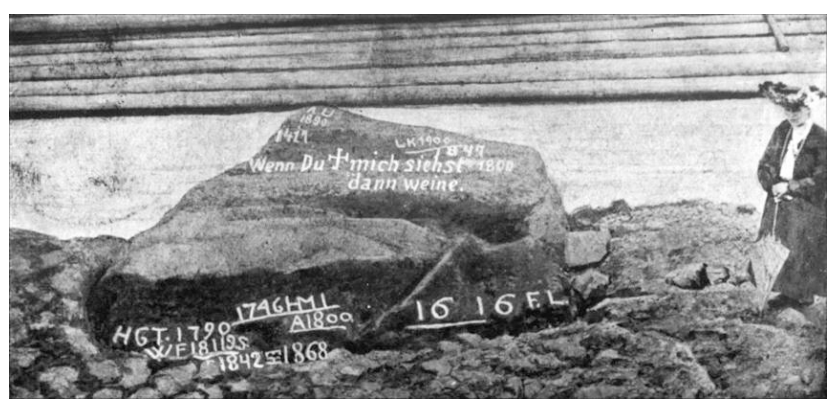

Figure 1. Hydrological drought of 1842 as indicated by a mark on a "hunger stone" on the river Elbe in Děčín-Podmokly (Bohemia). This stone appeared during a severe drought in 1904, when the picture was taken (O. Kotyza Archives).

was a necessary consequence of lack of fodder in some places, in which case cattle were taken to slaughter at very low prices due to sudden saturation of the market. This harm [...] will be experienced strongly in high prices of meat and dairy products, as well as in reduction of manure for soil fertility over time."

vi. Professional journals. Weather conditions and their detectable consequences, largely in the form of monthly overviews, were regularly published by professionals, mainly in agricultural and medical journals, often linked to specialist societies within a given country; examples include Magyar Gazda (Hungarian Farmer) and Orvosi Tár (The Medical Collection) in Hungary. These regular reports related to various parts of the country. For example, the weather conditions in July and August 1842, with certain health consequences, were described by the local medical officer in Uzhhorod (Ukraine) in what was then Uh County (Orvosi Tár, vol. 3/3, pp. 152-153). July: "There was great drought from the beginning of the month until the 22nd, and only in the last week [of the month] was there some rain that revived our vegetation." August: "In this month, except for the 1st, 7th and 27 th, the weather was very clear, dry and pleasant; light winds in the morning and evening alleviated the great heat. Medical conditions: In the hot and dry days of this month we continually observed [a rising number of] painful cases of urinary sand which, combined with incessant and prevailing intermittent fever (malaria), had even more desperate consequences. [... ] Among children, there was an epidemic of bronchitis."

vii. Professional papers. In the wake of certain outstanding extremes (particularly floods or storms), several kinds of professional papers related to such events appear. An example of a publication by Beyer (1843), related to the 1842 drought, has already been pointed out in Sect. 1.

\subsection{Instrumental series}

National meteorological services were established in the second half of the 19th century (e.g. in 1851 in the Austrian empire; Hammerl et al., 2001). Thus the year 1842 belongs rather to the period of early instrumental meteorological observations, despite the fact that a number of networks of meteorological stations were already in existence (e.g. see Bělínová and Brázdil, 2012, for Bohemia). Although various databases of meteorological measurements have been created for Europe (e.g. ECAD - see https://www.ecad.eu/ /dailydata/predefinedseries.php; last access: 19 April 2019), systematic homogenization of these observations is a relatively recent phenomenon (http://surfobs.climate.copernicus. eu/surfobs.php; last access: 19 April 2019; Squintu et al., 2019a, b). The HISTALP database (Auer et al., 2007), covering the Greater Alpine Region, is currently only one of a few publicly available sources of homogenized monthly temperature and precipitation series holding data concerning the period before 1842 (http://www.zamg.ac.at/histalp/index.php; last access: 19 April 2019). Such larger-scale endeavours aside, certain individual researchers and institutions have also contributed to the homogenization of long-term temperature and precipitation series in some European countries.

Using meteorological data from above-cited sources and others, only stations including the year 1842 and ending not earlier than in 1990 (to maintain the 1961-1990 reference period) were considered. This involved 33 series of monthly temperatures and 53 series of monthly precipitation totals. However, only 10 of these extending over the parts of Europe considered here and having both temperature $(T)$ and precipitation $(P)$ data were used for graphic presentation (Fig. 2). These series were for the greater part homogeneous and some of them at the very least quality checked (Paris $-T$; Stockholm - $P$; Cracow $-T, P$ ).

There exist a number of long-term hydrological series of water levels (from which discharges may be calculated later) and they include data for 1842. One example may be found in a paper by Novotný (1963), who created series of mean monthly discharges for the Vltava river at Prague (Bohemia) for the 1825-1957 period. Further, daily water levels of the river Danube at Vienna (Austria), for example, were published in the Wiener Zeitung for two profiles. One of these was situated at the Great Danube Bridge (Grosse Donaubrücke, demolished as part of Danube regulation works in 1870-1875, which was close to the current Floridsdorfer Brücke; Christian Rohr, personal communication, 2019), where recording started on 1 April 1826. The other was on the Danube canal (Franzensbrücke) since 1 January 1815. Both used units expressed in Vienna feet and inches (1 Vienna foot $=12$ Vienna inches $=31.608 \mathrm{~cm}, 1$ Vienna inch $=2.634 \mathrm{~cm})$. Water levels were also measured and published in Jelencor for the Danube at Budapest (Hungary) but until July 1842 measurements were only reported once or twice a week and only occasionally thereafter. De- 


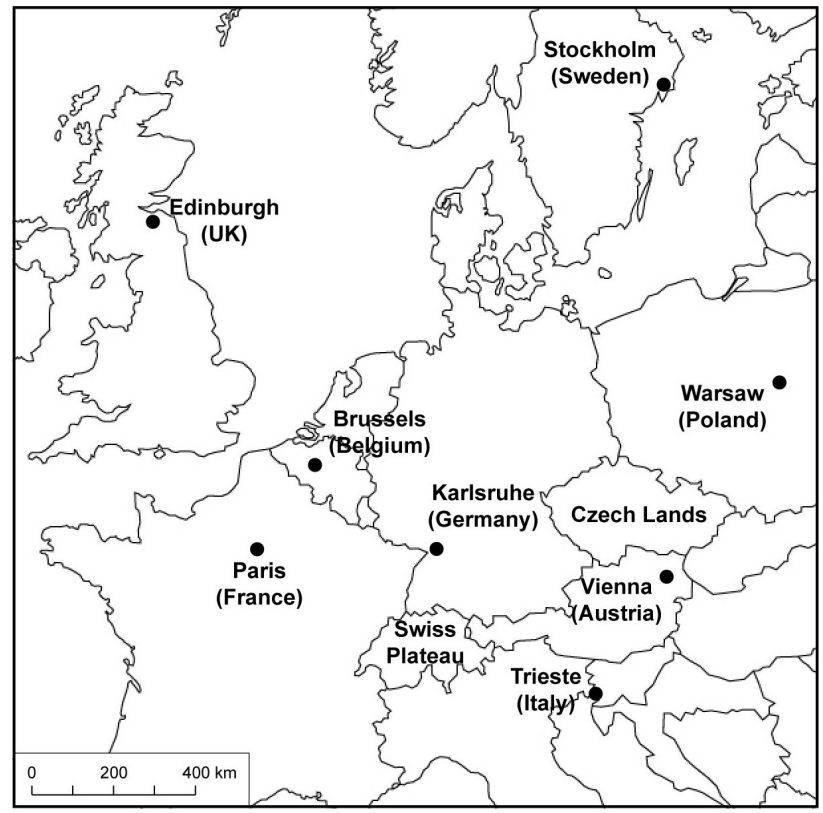

Figure 2. Selected European stations and regions used for graphic representation of temperature, precipitation, and drought indices in 1842 .

spite the availability of figures for water levels on other European rivers, and their particular use for the study of flood events, it is difficult to find daily water levels for 1842 for further rivers that are, at the very least, comparable with their adjacent years.

\subsection{Other data sources}

A spatial overview of seasonal precipitation patterns throughout Europe may be obtained from reconstructed totals for the 1500-2000 period calculated by Pauling et al. (2006). This reconstruction combines gridded values $\left(0.5^{\circ} \times 0.5^{\circ}\right)$ of the European lands $\left(30^{\circ} \mathrm{W}-40^{\circ} \mathrm{E}\right.$ and 30 $71^{\circ} \mathrm{N}$ ) for the years $1500-1900$ with the results of a gridded reanalysis for 1901-2000 (Mitchell and Jones, 2005). The reconstruction is based on long instrumental precipitation series, documentary-based precipitation indices, and natural proxies sensitive to precipitation signals, such as tree rings, ice cores, corals, and speleothems.

Sea-level pressure (SLP) patterns in the AtlanticEuropean area were examined in terms of the database of gridded SLP created by Luterbacher et al. (2002) (https: //www.ncdc.noaa.gov/paleo-search/study/6366: last access 19 April 2019). Atmospheric circulation was examined in terms of the North Atlantic Oscillation Index (NAOI) in two versions and the Central European Zonal Index (CEZI). The NAOI series, after Jones et al. (1997) and taken from the CRU website (https://crudata.uea.ac.uk/cru/data/nao/; last access: 19 April 2019), calculates on the basis of data from Gibraltar and the Reykjavik area of Iceland, while NAOI, after Luterbacher et al. (1999), takes into account normalized differences between SLP means of four $5^{\circ} \times 5^{\circ}$ (latitude and longitude) grid points over the Azores and over Iceland. CEZI is calculated as the difference in the standardized mean SLP, averaged for the grid points $35^{\circ} \mathrm{N} / 0^{\circ}, 35^{\circ} \mathrm{N} / 20^{\circ} \mathrm{E}$, $40^{\circ} \mathrm{N} / 0^{\circ}, 40^{\circ} \mathrm{N} / 20^{\circ} \mathrm{E}$ and $60^{\circ} \mathrm{N} / 0^{\circ}, 60^{\circ} \mathrm{N} / 20^{\circ} \mathrm{E}, 65^{\circ} \mathrm{N} / 0^{\circ}$, $65^{\circ} \mathrm{N} / 20^{\circ} \mathrm{E}$ (Jacobeit et al., 2001).

Indicative fluctuations in the prices of agricultural products and goods were derived from series of prices for wheat, rye and barley over the $1655-1872$ period collected for Prague (Czech Lands) by Schebek (1873). Moreover, many newspapers have always reported on the market prices of various agricultural crops (particularly grain), as well as other commodities.

\section{Methods}

Documentary data extracted from the basic sources described in Sect. 2.1 were first critically evaluated with respect to the credibility of sources, their dating, and the contents of the reports. Because of possible exaggeration of drought and its consequences and impacts (e.g. in newspapers), the content of every report was carefully evaluated with respect to the events described. In the event of doubt, these were checked with other sources, both in temporal and spatial contexts. This also involved some confrontation of documentary data with measured meteorological variables. If any such report was identified as doubtful, it was excluded from further analysis. In further checking of reports, obsolete place names were converted into their recent more accessible form and the corresponding country added. Documentary data, by nature of their qualitative character, were employed, in particular, to descriptions of the character of hydrological, agricultural, and socio-economic droughts from the point of view of environmental and societal impacts, as well as human responses. Further to such general characterization, descriptions of droughts were supplemented by numerous examples from other European countries. However, space and purpose have dictated that only a small proportion of the huge amount of information collected could be included in this paper. Original narrative sources from the archives have been quoted only in the case that they have not been previously translated into English, edited, or published.

Gridded totals over the lands of Europe by Pauling et al. (2006) were used to show spatial precipitation distribution in winter (DJF) 1841/1842, spring (MAM), summer (JJA), and composite winter-summer (DJF-JJA) seasons for 1842. The corresponding totals were expressed as deviations from the 1961-1990 reference period seasonal means on the one hand and as percentages of these reference means on the other (Fig. 3). Daily mean temperatures, daily precipitation totals, and their cumulative values for the PragueKlementinum station (Fig. 4) served to illustrate weather changes during 1842 . A range of long-term monthly tem- 
perature and precipitation series put the year in question in perspective in terms of annual variation. To examine temperature, monthly variations during 1842 were presented as deviations from the 1961-1990 reference period, while the monthly precipitation totals for 1842 were expressed as percentages of the corresponding reference (Fig. 5). These series were then worked up to calculate monthly drought indices: (i) Standardized Precipitation Index for 1 month - SPI1 (McKee et al., 1993); (ii) Standardized Precipitation Evapotranspiration Index for 1 month - SPEI-1 (Vicente-Serrano et al., 2010); and (iii) $\mathrm{Z}$ index (Palmer, 1965) (Fig. 6). For SPEI-1 and $\mathrm{Z}$ index, the calculation herein used the Thornthwaite method to estimate the potential evapotranspiration and data from the 1901-2000 period as a reference period for all three drought indices. The SPI- 1 and SPEI- 1 were further complemented by their calculations for 3, 6, and 9 months.

In order to investigate the synoptic patterns current in the driest months of 1842 (January, February, April-August), monthly SLP maps for the Atlantic-European area were created and also expressed as deviations from the SLP means in 1961-1990 (Fig. 7). Further, the synoptic patterns associated with the 1842 drought were also compared with those that typically occurred during other extremely dry months in central Europe during the 1850-2010 period, as defined by Brázdil and Trnka (2015). Using monthly series of $Z$ index and SPEI-1 for the above period, the first step was to select the $20 \%$ that made up the most severe droughts. Only those months occurring within the selection by the standards of both indices were denoted as extremely dry. The numbers of such extremes for each month from April to August in the 1850-2010 period varied from 27 (August) to 31 (April, May). Typical SLP fields and their variability were constructed as the mean (standard deviation) of all extremely dry months using the HadSLP2 database (Allan and Ansell, 2006). Next, the SLP fields of the 1842 drought were compared with the mean and variance in the SLP fields of the extremely dry months defined above used as a reference. Moreover, overall correlations between 1842 SLP fields and the mean SLP fields of extremely dry months were calculated in order to evaluate the overall degree of similarity.

Above maps for 1842 were further supplemented by the annual variations in mean monthly NAOI and CEZI in order to investigate any possible further circulation involvement with droughts (Fig. 8).

In light of their general similarities, the features common to the general impacts of hydrological, agricultural, and socio-economic droughts in Europe are always mentioned. This general information is supplemented by many examples from documentary evidence reporting the individual features of droughts, their consequences, and human responses to them. Moreover, measurements of water levels or calculated discharges expressing their annual variations have been used for further characterization of hydrological drought (Fig. 9).

\section{Results}

\subsection{Spatio-temporal variability of the weather in 1842}

\subsubsection{Precipitation patterns}

The spatial DJF, MAM, and JJA precipitation patterns for the driest parts of the 1842 year over the European lands, based on gridded precipitation totals by Pauling et al. (2006), appear in Fig. 3. Totals for 1842 are expressed both as deviations from the reference 1961-1990 seasonal means and as percentages of means derived from this reference period. Dry patterns in DJF appear especially from eastern France to the western part of central Europe and then in a broad area around the Black Sea (Fig. 3a). DJF precipitation shows decreases of more than $20 \%$ compared to the reference means, creating a broad belt stretching from eastern France to eastern Europe (Fig. 3b). Particularly dry in MAM was a band of territory stretching over western Europe from southern Scandinavia to northern Spain, including a large part of the British Isles (Fig. 3c), with totals more than $20 \%$ below the reference means. Other areas with relatively marked MAM precipitation decreases extended from the Black Sea to Poland, further in the Balkan region close to the Adriatic Sea, and in north-eastern Europe (Fig. 3d). Lower precipitation in JJA extended from the north of the British Isles to southern Scandinavia and notably from France, over central Europe, to eastern Europe (Fig. 2e). Areas from the North Sea running south-east, with slightly lower totals in a belt from northwestern Poland to southern Germany were the driest in relative terms (more than $20 \%$ below the JJA reference means) (Fig. 3f). The distribution of JJA precipitation influenced the picture for composite DJF-JJA patterns (Fig. 3g), in which a dry belt from south-east Scandinavia to north-east France predominated in relative expression (Fig. 3h). However, generally lower DJF-JJA precipitation totals were experienced in a broad band extending from the British Isles and France to eastern Europe (Fig. 3h). SON precipitation (not shown) demonstrated somewhat wetter patterns to the south of ca. $52-53^{\circ} \mathrm{N}$ and drier patterns to the north of this latitude.

\subsubsection{Annual variations in temperature, precipitation, and drought indices}

Fluctuations in daily mean temperatures and daily precipitation totals during 1842 at the Prague-Klementinum station appear in Fig. 4. Compared with the 1961-1990 reference period, temperatures remained below their corresponding means for the greater part of the year, particularly in January and February, the first part of April, and at the turn of October/November. A very consistent cold period persisted from the second half of September to early December. Clearly warmer patterns compared to the 30 -year mean occurred only in August (Fig. 4a). The highest daily precipitation total achieved only $13.8 \mathrm{~mm}$, on 8 June. The deficit in precipitation totals, continuously growing from mid-April to 
DJF
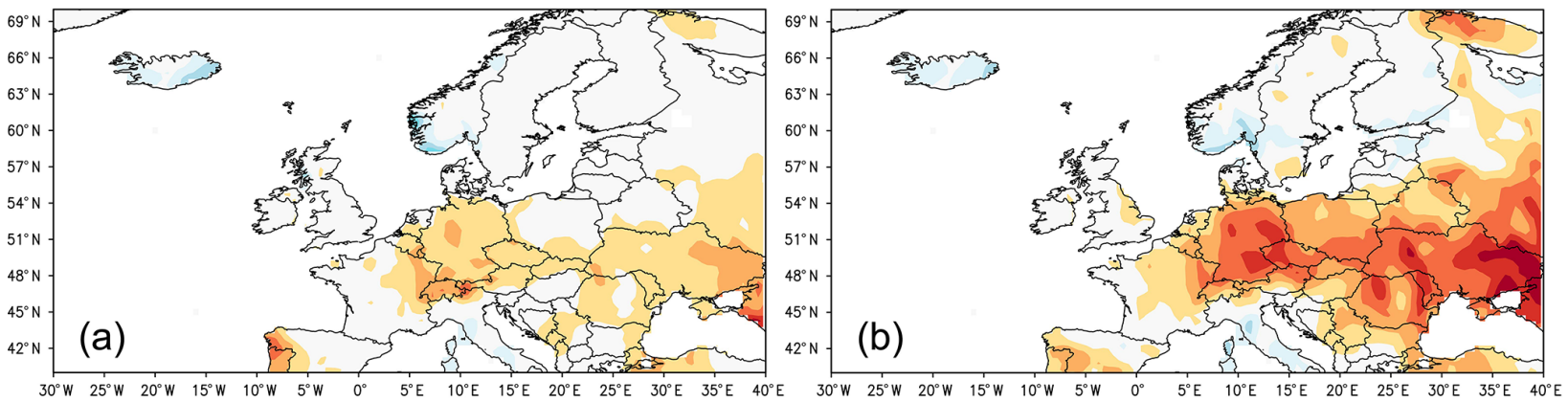

\section{MAM}
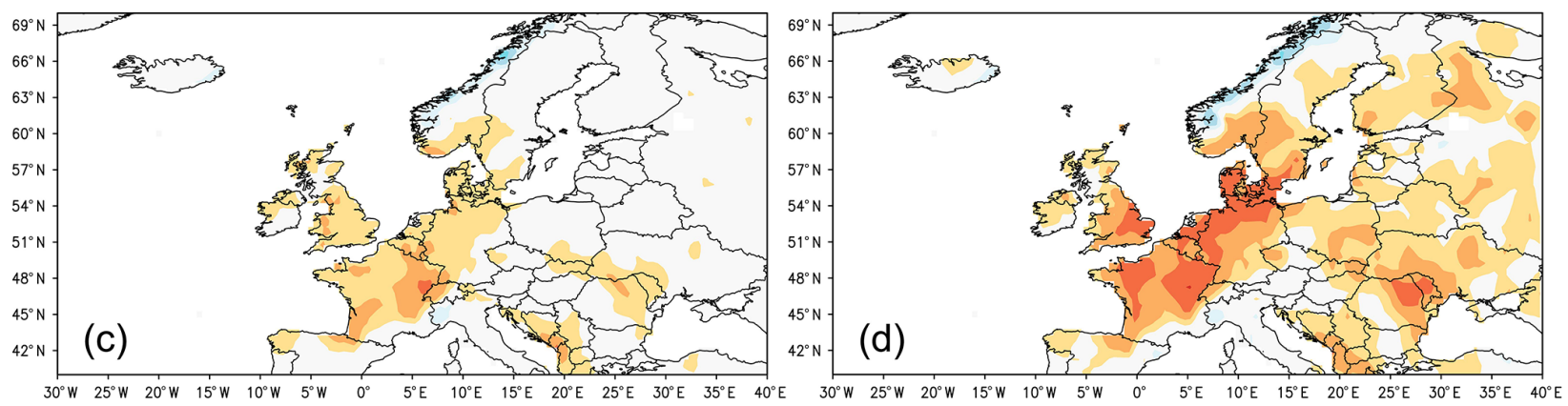

JJA
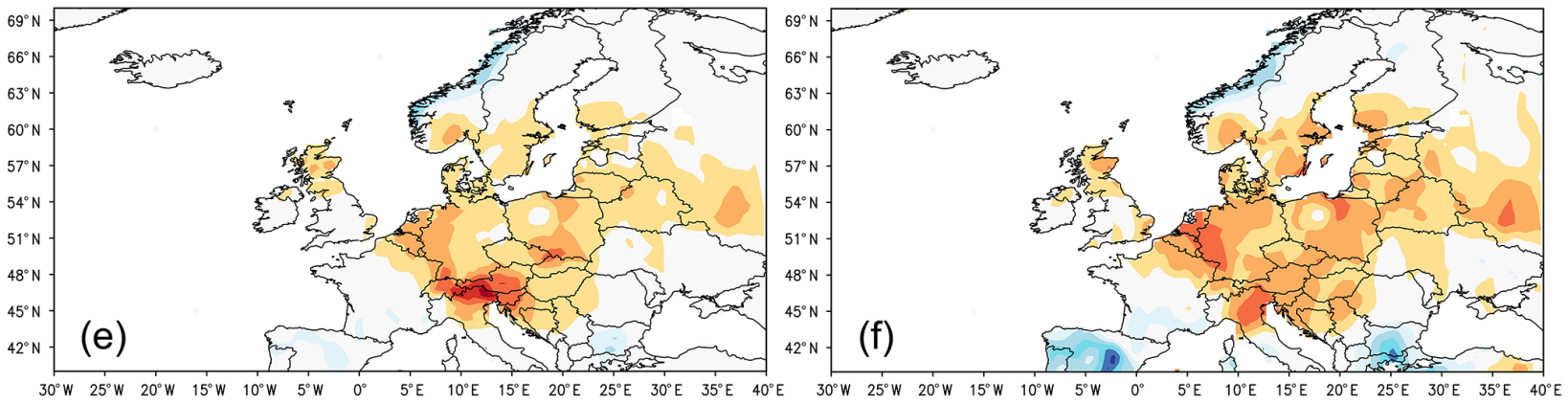

DJF-JJA
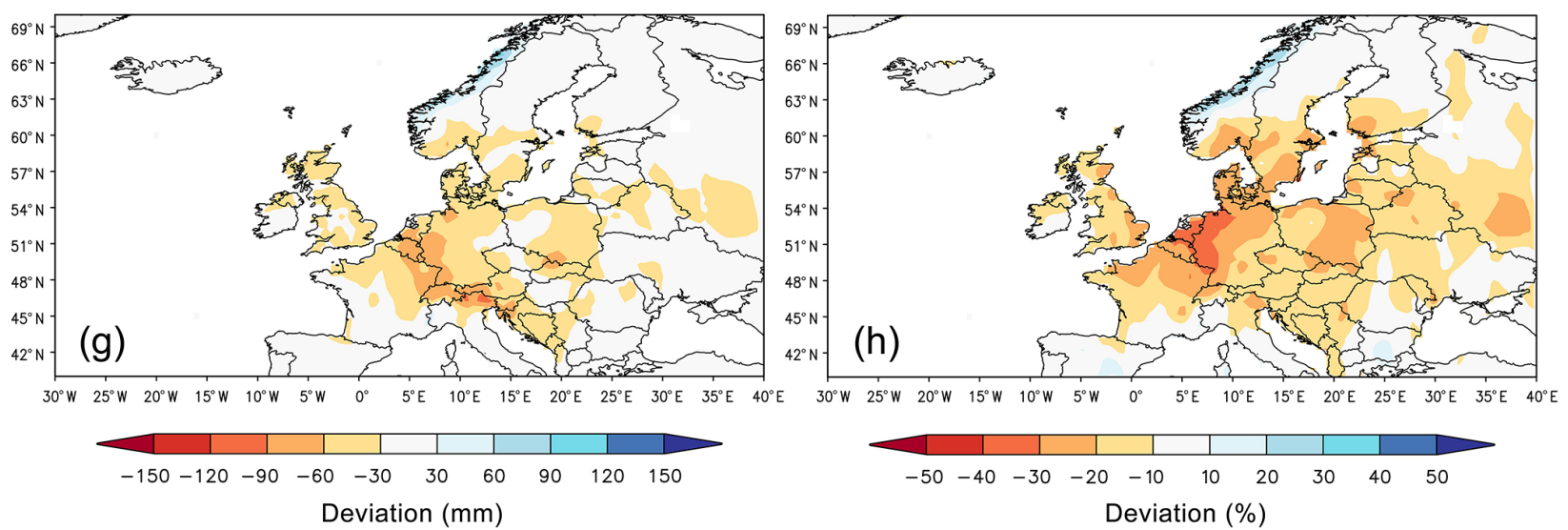

Figure 3. Precipitation patterns of DJF (a), MAM (c), JJA (e), and DJF-JJA (g) and their expression as percentages of the corresponding parts of the seasonal means in the 1961-1990 reference period (b, d, f, h) over the European lands (data from Pauling et al., 2006). 

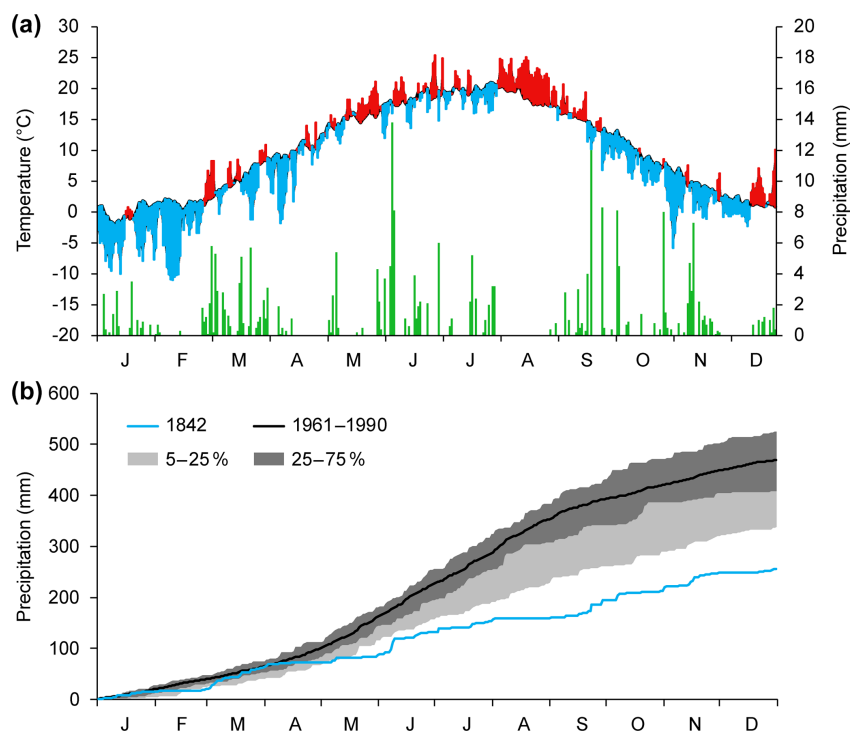

Figure 4. Temperature and precipitation for 1842 at the PragueKlementinum station: (a) annual variation in daily mean temperatures (compared with the 1961-1990 mean variation) and daily precipitation totals for 1842; (b) cumulative daily precipitation totals for 1842 in comparison with the 1961-1990 reference period (the interquartile (75\%-25\%) and lower quartile to 5th percentile (25\%-5\%) bands of the 1961-1990 period are shown).

the end of 1842 , finally reached $215 \mathrm{~mm}$ compared to the 30 year mean of $470 \mathrm{~mm}$ (Fig. 4b). From around April 1842 to the end of the year, cumulative precipitation figures were below the value for the 5th percentile of the 1961-1990 period. Helping to complete the picture, the annual frequency of precipitation days with a total of $\geq 0.1 \mathrm{~mm}$ in 1842 achieved $126 \mathrm{~d}$ compared with the mean of $151.7 \mathrm{~d}$ in 1961-1990. In terms of frequencies of days with totals of $0.1-1.0,1.1-5.0$, $5.1-10.0$, and $\geq 10.1 \mathrm{~mm}$, the differences in precipitation days between 1842 and the reference period were at their highest for the last-mentioned interval ( $2 \mathrm{~d}$ against $10.4 \mathrm{~d}$ ). During the driest period, from April to August 1842, only 30 precipitation days were recorded compared with $67.7 \mathrm{~d}$ in the 1961-1990 period. August was outstandingly dry with only 2 precipitation days compared to the mean of $13 \mathrm{~d}$ for this month.

Documentary sources usually report extended periods without rain or when the first rain falls after a dry period. For example, on Greenock and Glasgow in Scotland, renowned even in that proverbially moist land for their damp and rainy nature, not a single raindrop fell in the whole of April (Wiener Zeitung, 28 May 1842). In central Transylvania the Siebenbürger Bote (26 May 1842) reported a drought that lasted until 22-25 May, when torrential rain led to a flash flood, but in other areas drought continued without the usual late-May rain (Erdélyi Híradó, 21 June 1842). To emphasize the extremity of such weather, reports often add information about high temperatures. For example, a story dated 1 September from Trieste in Italy reported that since mid-June there had been virtually no rainfall in the vicinity and temperatures were almost constantly between 22 and $25^{\circ}$ Réaumur $\left({ }^{\circ} \mathrm{R}\right)$, i.e. $27.5-31.2^{\circ} \mathrm{C}$ (Journal de Bruxelles, 15 September 1842). In Troitsk, Russia, not a drop of rain fell from the end of June onwards and on 27 July temperatures rose to 28 to $32^{\circ} \mathrm{R}$ (i.e. $35-40^{\circ} \mathrm{C}$ ). This heat, together with dry westerly winds, desiccated the soil to a depth of $150 \mathrm{~cm}$ (Le Messager de Gand, 19 October 1842). Although such daily entries have been reported for many European places, they lack sufficient systematic character to cite.

To examine the annual structure of weather in 1842, certain European meteorological stations or regions were selected to describe temperature and precipitation on the basis of monthly values (Fig. 5). Despite existing regional differences, cooler and drier patterns prevailed in JanuaryFebruary. After above-normal March precipitation, dry patterns prevailed at various degrees of intensity from April to August. August was also the month with the highest positive temperature deviation.

Stations and regions appearing in Fig. 5 (except for the Swiss Plateau, which was replaced by Vienna because data were absent) were used to calculate drought indices expressing the actual drought, namely SPI-1, SPEI-1, and Z index (Fig. 6). Indices are expressed in real values and their negative figures reflect drier patterns. While SPI-1, expressing variations of precipitation totals, indicates a great lack of precipitation (e.g. see the lowest values for April in Stockholm and for August in Warsaw), SPEI-1 combines the effects of precipitation with temperatures, from which evapotranspiration is estimated. However, annual variations in both SPI-1 and SPEI-1 indices are very similar. The third indicator, the $\mathrm{Z}$ index, used for calculation of the Palmer Drought Severity Index (PDSI) and representing soil moisture patterns, tends to show a consistent dry period, as seen for JJA in Trieste and AMJJA in Paris, Karlsruhe, and Vienna, as well as the Czech Lands, for which generally increasing intensity from April to August is apparent. In Edinburgh, the drought persisted unremittingly from April to December. In order to present the accumulated effects of drought, SPI, and SPEI values for 3, 6, and 9 months were also calculated (see Figs. S2 and S3). Compared with Fig. 6, the features of drought are well preserved but annual variation in indices is more smoothed, partly shifted to the second half of the year, and demonstrating a degree of persistence of drought patterns.

\subsection{Synoptic patterns in 1842}

SLP patterns in the Atlantic-European area for January, February, and all months between April and August 1842, and their deviations with respect to the corresponding 19611990 reference period, appear in Fig. 7. In January, eastern and central Europe and part of Scandinavia were under the influence of high pressure from the east, becoming far weaker towards south-western Europe (Fig. 7a). In February, 

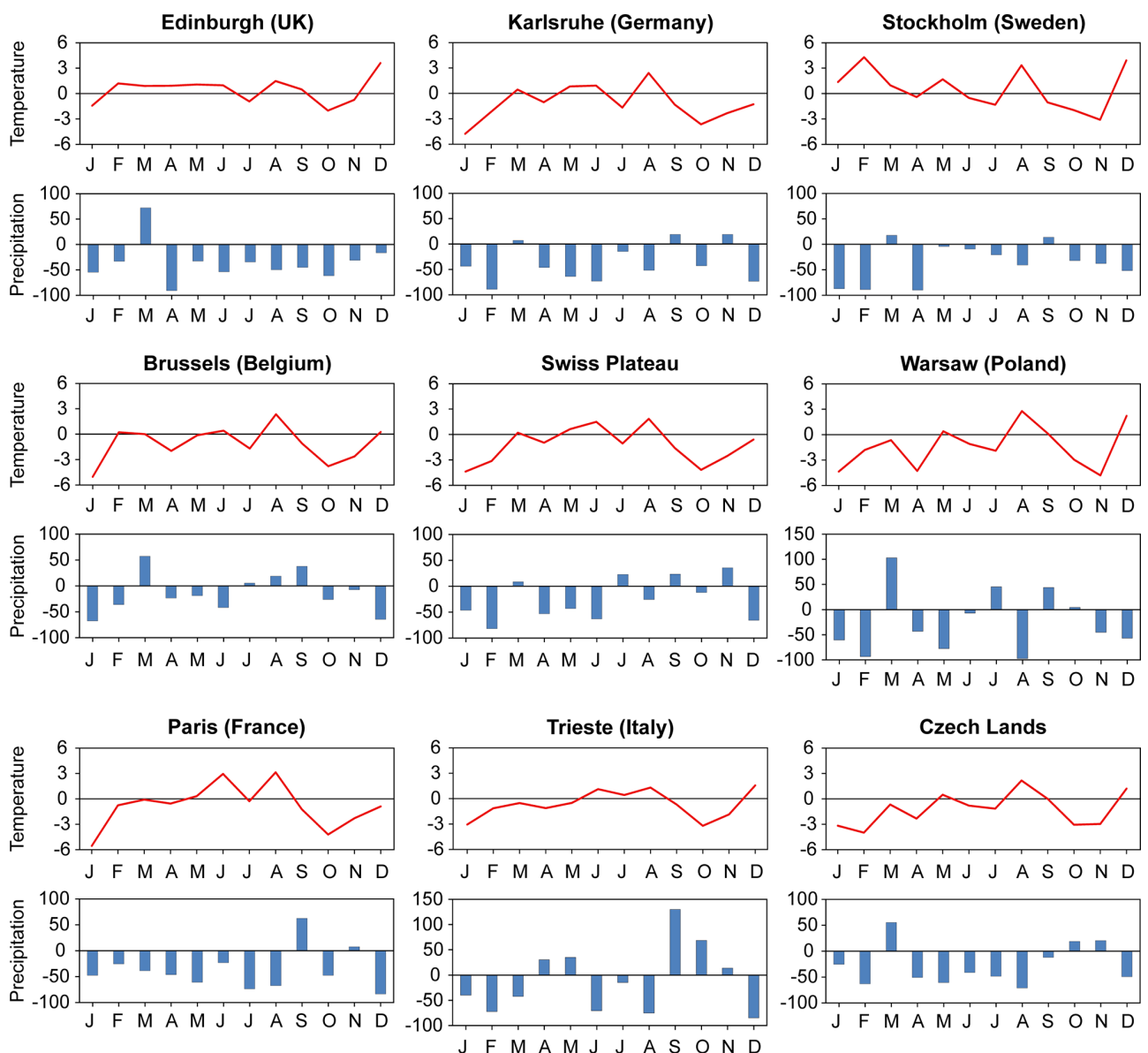

Figure 5. Annual variation in air temperature and precipitation in 1842 for selected European meteorological stations and regions. Temperatures are expressed as deviations from the 1961-1990 reference period and precipitation totals as percentages of corresponding 30-year means.

a considerable portion of Europe was under a ridge of high pressure with the anticyclone located to the north and northwest of the Black Sea, and a high-pressure system southwest of the Iberian Peninsula (Fig. 7c). In April, an extensive high-pressure system centred over the northern British Isles influenced weather patterns over the greater part of Europe (Fig. 7e). In May, a pressure col extended over much of western Europe, running between a high-pressure area southwest of the Iberian Peninsula and another high over eastern Europe (Fig. 7g). In June, most of Europe lay within a belt of high pressure extending from the Azores High, located far south-west of the Iberian Peninsula; a distinct low appeared in northern and north-eastern Europe (Fig. 7i). A similar distribution of SLP patterns held for the following month of July (Fig. 7k). In August, a large part of Europe lay within a belt of high pressure running from south-west to north-east with the Azores High west of the Iberian Peninsula and an isolated anticyclone over the Baltic Sea (Fig. 7m). All over Europe, in all the months analysed except July (Fig. 71), an area of considerable pressure increases compared to the 1961-1990 means was evident in one area or another (Fig. $7 \mathrm{~b}, \mathrm{~d}, \mathrm{f}, \mathrm{h}, \mathrm{j}$, n).

Compared with other extreme droughts that occurred over the territory of the Czech Lands, in 1842 only the April SLP field was exceptional in that it shared only $10 \%$ of variability with the mean SLP of April extremes during the 1850-2010 period. The most significant feature in the April 1842 SLP field was a region of high pressure centred on the northern British Isles. Synoptic patterns for the other months (MayAugust) in 1842 were more similar to the mean SLP of corresponding extremely dry months; they shared from $64 \%$ (August) to $90 \%$ (June) variability. Compared to the mean extreme SLP fields for 1850-2010, the 1842 SLP patterns do not show unambiguous pattern for all months. There occurred positive deviations in north-western Europe and negative deviations in north-eastern Europe, especially in April, June, and July, while the opposite dipole pattern occurred in May and August.

Other available circulation indices were also used to describe relevant circulation patterns in Europe in 1842 (Fig. 8). According to Jones et al. (1997), a clearly expressed positive 

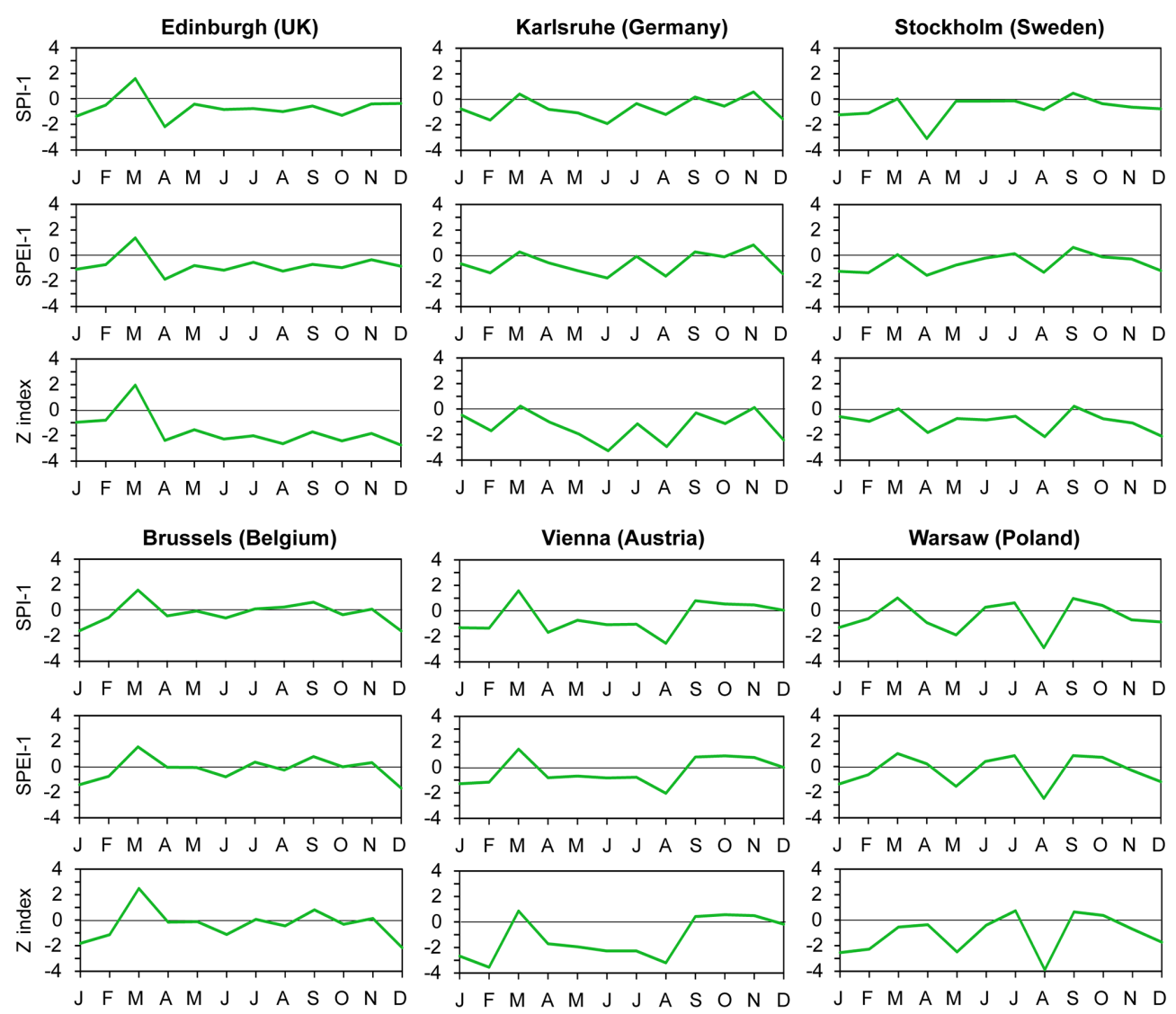

J F M A M J J A S O N D
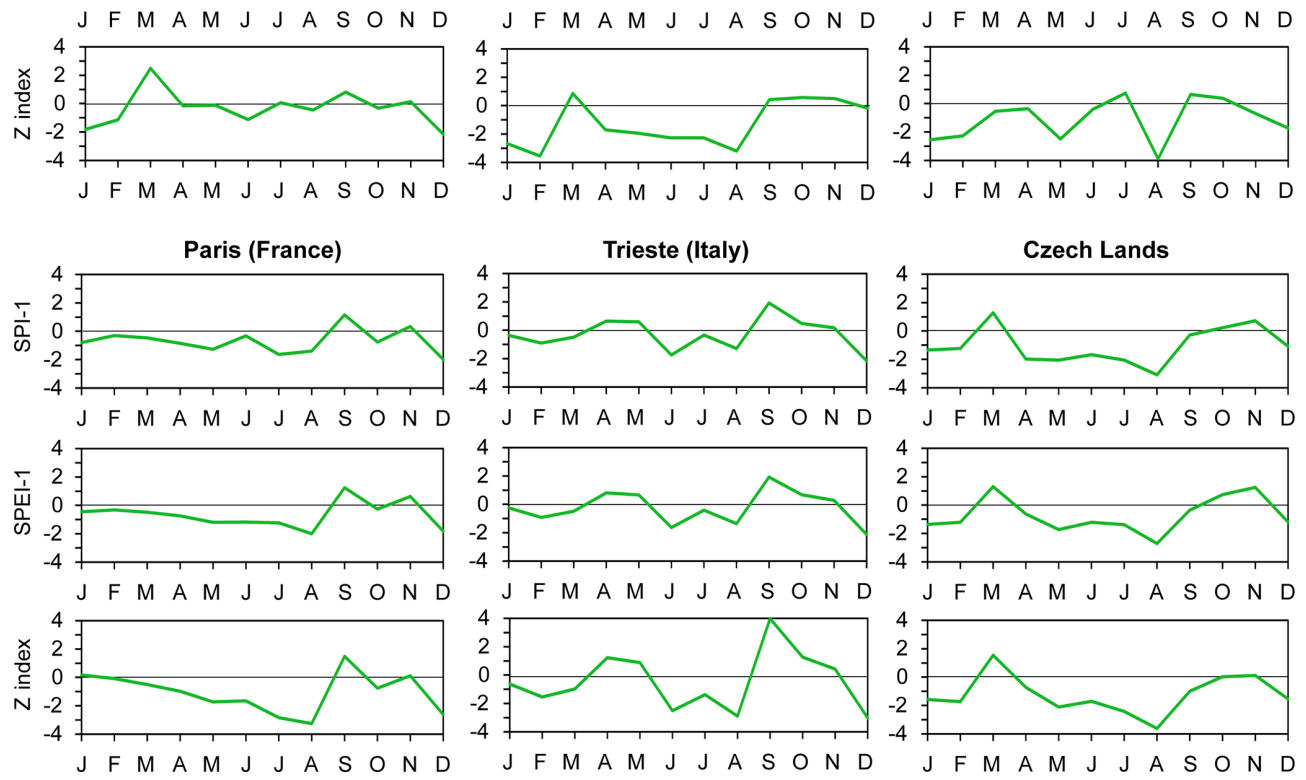

Figure 6. Annual variation in SPI-1, SPEI-1, and Z index for selected European stations and regions in 1842.

NAOI mode prevailed in January-March and negative modes in June-July and September-November. According to Luterbacher et al. (1999), there were remarkably well-expressed positive NAOI modes in February-March, May, and August, while negative modes were clearly pronounced in April and also in the SON months. Analysing CEZI (Jacobeit et al., 2001), we found a positive mode predominant in March and a negative mode in September. Because positive modes of all three indices reflect rather western airflow from the Atlantic Ocean into the studied part of Europe, Fig. 8 demonstrates a complicated relationship of precipitation and/or drought patterns to circulation indices.

\subsection{Impacts and human responses to the 1842 drought}

\subsubsection{Hydrological drought}

The weather patterns of 1842 were reflected in low water levels and discharges on several rivers. For example, the daily water levels of the river Danube at Vienna, published regularly in Wiener Zeitung, were recorded for the main river 

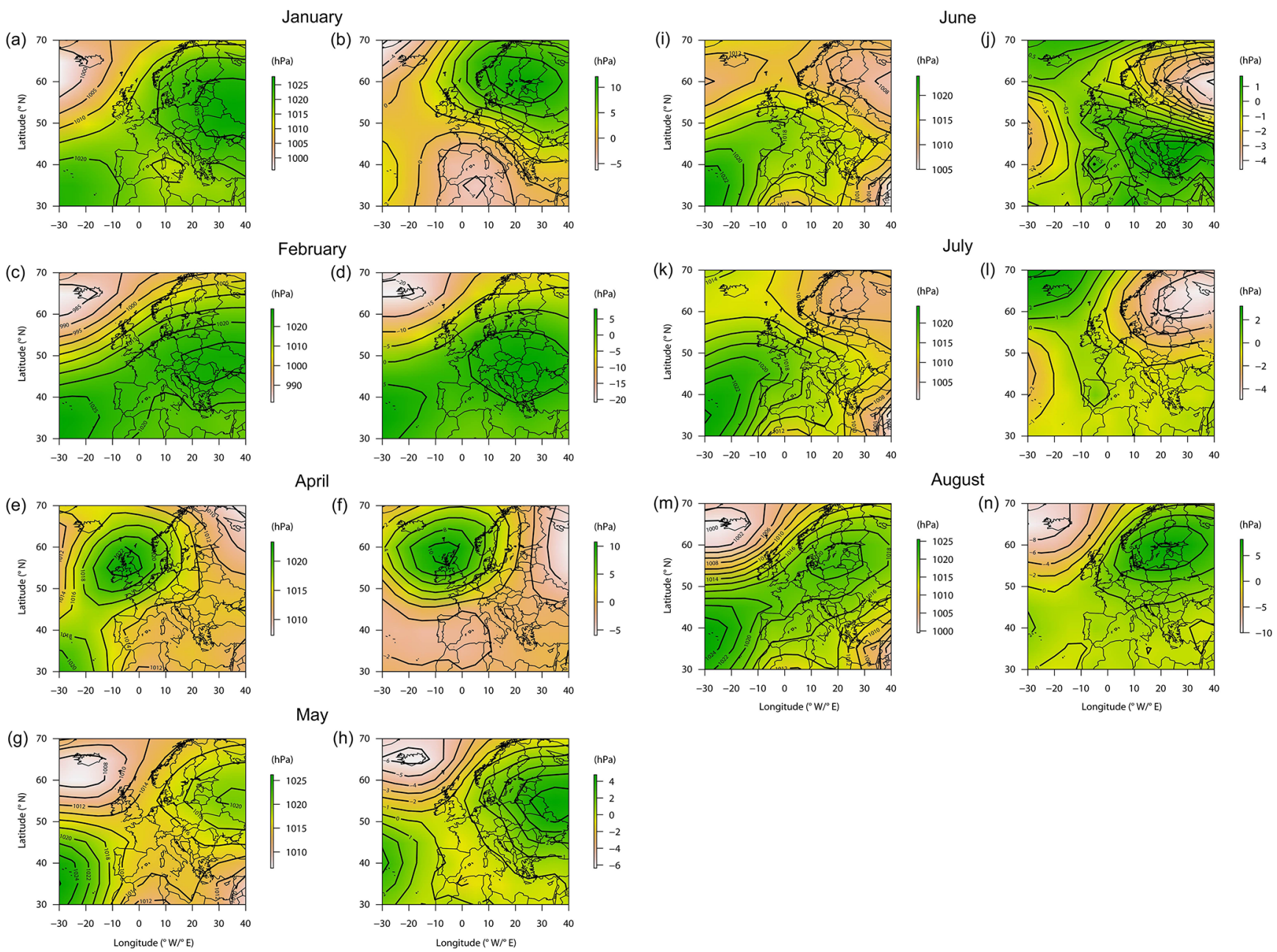

Figure 7. Mean sea-level pressure and deviations with respect to the reference (1961-1990) period means in the European-Atlantic area for the months of January (a, b), February(c, d), April (e, f), May (g, h), June (i, j), July (k, l), and August (m, n) 1842.

at the Great Danube Bridge as well as on the river channel (see Sect. 2.2). Since both profiles express identical changes, Fig. 9 shows fluctuations in daily water levels at the bridge profile in 1842 in comparison with the corresponding levels from 1841 and 1843. After very low water levels in JanuaryFebruary 1842 , related to the channels being frozen over, water levels were below those of the 2 adjacent years in June-July and then from mid-August to around the beginning of November with a very strongly expressed declining trend. A further considerable decrease appeared around mid-December. The mean annual discharge of $3342 \mathrm{~m}^{3} \mathrm{~s}^{-1}$ for the year 1842 is the 11th lowest value in the long-term annual series of Danube discharges at Vienna in the 18282011 period. Tendencies similar to those observed in Vienna are recorded for the Danube at Budapest: from not particularly high water levels in May and June, there was a steady decrease with a particular drop in early July; water levels then continued to remain somewhat low, although with min- imal decrease. Very low water levels appeared in December (Nemzeti Újság, 21 December 1842).

On the river Vltava in Prague, very low discharges were recorded during a dry January and February period (48 and $46 \mathrm{~m}^{3} \mathrm{~s}^{-1}$ respectively). After a steep increase to the annual maximum in March $\left(255 \mathrm{~m}^{3} \mathrm{~s}^{-1}\right)$, they began to decrease (the most dramatic drop - by $119 \mathrm{~m}^{3} \mathrm{~s}^{-1}$ - occurred between April and May) to their lowest values in July-September, with the annual minimum in August $\left(35 \mathrm{~m}^{3} \mathrm{~s}^{-1}\right)$. A slight increase followed (Novotný, 1963). Very low water stages were also recorded on the river Elbe, with epigraphic testimony appearing as a mark for 1842 on the hunger stone at DěčínPodmokly in Bohemia (see Fig. 1). The emergence of a similar hunger stone on the German part of the Elbe in Dresden and "the near disappearance" of this river around Pirna was also reported in Lemberger Zeitung (9 September 1842). The waters of the rivers in south-eastern Poland ran at unusually low levels and some rivers even dried out (Szewczuk, 1939). The exceedingly low water level recorded for the river Tisza 

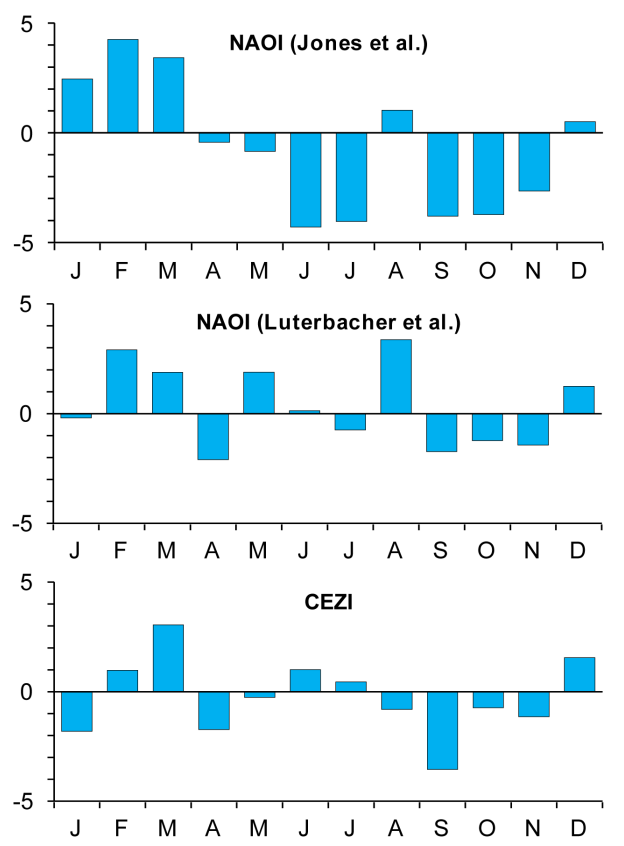

Figure 8. Annual variation in mean monthly NAOI (Jones et al., 1997; Luterbacher et al., 1999) and CEZI (Jacobeit et al., 2001) in 1842.

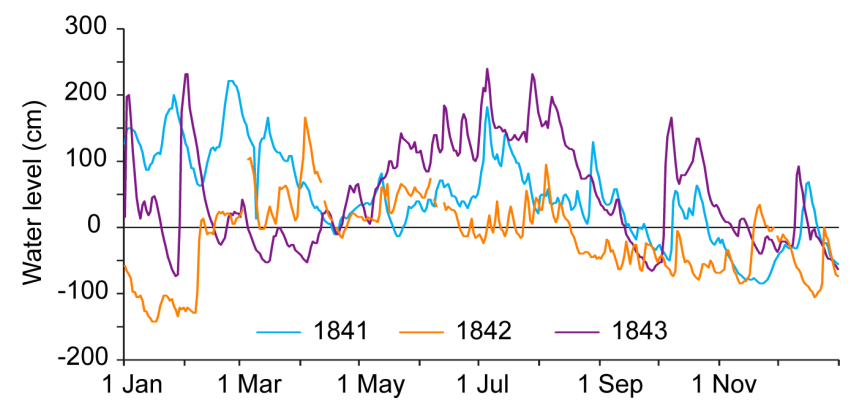

Figure 9. Annual fluctuations in daily water levels of the Danube at Vienna in the profile of the Great Danube Bridge during the years 1841, 1842, and 1843 (data extracted from Wiener Zeitung).

in Szeged (Hungary) in 1842 later became the zero point for water level measurements at that point (Botár and Károlyi, 1971). Records of daily water levels there suggested a steady decrease from April with the lowest values in August and September (AS1). On the river Seine at Paris, the water level dropped for $52 \mathrm{~d}$ below the zero point on the Pont de la Tournelle scale, established already during an extraordinary drought in 1719 (Belgrand, 1872).

Low water levels in the Lake Fertô/Neusiedl, today located on the Austrian-Hungarian border, were also noted for 1842 (Éló, 1937); the planning and ground investigations for the drainage of the southern Balaton wetlands, which usually took place at times of low water level, were carried out in this year (Szaplonczay, 1914).
A very rich body of documentary sources report a general lack of water in 1842, when many wells and springs dried out. Brooks and small watercourses ran dry. In Älvkarleby (near Gävle, Sweden), one arm of a waterfall dried out completely and the main arm carried so little water that it was possible to cross it on foot (Wiener Zeitung, 21 October 1842). Absence of water on even large rivers led to interference with commercial ship transport for several months. In France, shipping on the river Seine at Paris was disrupted for around 4 months (Fuster, 1845). A newspaper story dated 29 June from Regensburg (Germany) reports that the BayernWürttemberg Steam Navigation Company cancelled a cruise on the river Danube (Linzer Zeitung, 6 July 1842). A similar situation pertained to almost all the usually navigable German rivers. From Dresden, reports indicate that transport on the river Elbe was suspended on 11 July. Cessation of steamship traffic is also reported for the river Main at Frankfurt am Main on 5 July, and a similar situation was mentioned for the river Moselle (Allgemeine Preußische Staats-Zeitung, 9 and 14 July 1842). The ferry between Rotterdam and Venlo (the Netherlands) had to be suspended due to persistent low water levels on the river Maas or Meuse which "will became non-navigable if the current unprecedented drought does not cease soon" (Algemeen Handelsblad, 2 September 1842, p. 1). As the drought went on, the levels of the river Weser in north-western Germany fell into a state not seen for 200 years. An enormous quantity of dead fish led to a foul odour of putrefaction and their remains had to be removed by the cartload (L'Indépendance Belge, 2 September 1842). It was possible to wade across even such large rivers.

Problems arising out of scarcity of water were especially acute in towns and cities. When a general and urgent lack of drinking water started to occur in Middelburg, the capital of the province of Zeeland in the Netherlands, the town authorities found themselves obliged to send a ship to "mainland" Holland on 8 June in order to provide it (Nederlandsche Staatscourant, 11 June 1842). According to a report from the city of Goes on the island of ZuidBeveland (the Netherlands), dated 13 June, good drinking water was so scarce that many people were using bad water and adverse health consequences were feared (Vlissingsche Courant, 17 June 1842). Because the flat islands in the southwest of the Netherlands are surrounded by seawater and tidal rivers, and have no freshwater rivers or lakes, they are vulnerable to drought. Their situation, therefore, may be worse than that in other parts of the Netherlands. However, the mayors of other Dutch cities such as Breda (Bredasche courant, 14 August 1842) and The Hague (Dagblad van 's Gravenhage, 19 August 1842) took measures to limit the use of water. A report that appeared on 31 August indicated that one had to travel 7 miles (ca. $51 \mathrm{~km}$ ) from Hamburg (Germany) to Glückstadt, higher up the Elbe, or 4 miles (ca. $29 \mathrm{~km}$ ) to Stade for drinking water because local springs were completely dry and the lower Elbe water was too brackish to be used for drinking (Algemeen Handelsblad, 5 Septem- 
ber 1842). Even the Alps had water problems, as reported, for example, in Stuttgart (Germany) on 20 April (Allgemeine Preußische Staats-Zeitung, 27 August 1842, p. 1015): “The worst [of it] is for the inhabitants of the Alps, where a lack of water has achieved the highest degree, and true caravans with water tanks travel several hours [down] to valleys to ensure necessary water." In Trieste (Italy), based on a report dated 1 September, more than 300 public water points ("fountains") were dry. Serving maids were forced to wait for hours at the few fountains that still had water before they could fill their buckets (Journal de Bruxelles, 15 September 1842).

Lack of water was fatal to the operation of water mills and many were simply forced out of operation. A concise description of the problems facing milling was given by the chronicler Václav Krolmus for Bohemia (Krolmus, 1845, pp. 127-128): "Two-thirds of [water] mills were standing [idle in the] drought. It went badly for milling; lone [i.e. isolated] millers sought mills on larger rivers where they could grind grain for their own houses. People had to travel 6-7 hours to distant rivers such as the Elbe, Jizera, Vltava, Ohře and Mže [now Berounka]. Further, [even] on large rivers, millers were forced to allow time for sufficient water to build up and people had to wait several weeks [for milling]; all this was all the more [valid] on brooks that had only weak and tiny active springs. At that time millers in some places bought water from the large ponds owned by the nobility and collected enough to make milling for a few hours possible. Millers milled for one another."

\subsubsection{Agricultural drought}

When addressing plant growth, documentary sources tend to give preferential attention to rain events and their abundance. For example, Anton Pejšek from Zlončice (Bohemia) mentioned the drought of 1842 and problems for crops in these terms in several cases: the first rain of spring on 4 June wetted the soil to a depth of 1 (Vienna) inch (ca. $2.6 \mathrm{~cm}$ ). As late as 2 August, the soil was wetted to the extent of "a tiny little furrow"; on 17 September this grew to three-quarters of a furrow and by 2 October had extended to the whole furrow so that autumn sowing went well (Robek, 1958a). Lack of rain was the anticipated forerunner of a bad harvest, as documented by the French La Patrie (16 June 1842, p. 3): “Ordinarily, says the Patriote de la Meurthe et des Vosges [at Nancy], the month of June is rainy in our countryside; this is not the case this year: the pleasant weather is a real calamity. For two months, hardly a drop of water has fallen on our plains and in our valleys. Hay harvesting will be less productive than a year ago. Wheat suffers from this pitiless drought; the vine alone maintains a beautiful appearance. May we soon see some clouds in this sky, the [constant] serenity [of which] is desperate." A similar situation was reported from northeastern England (The Morning Chronicle, 23 June 1842, p. 6): "the crops are light, and if we are not favoured with mois- ture from the clouds in a short time, the whole of the hay crop will prove extremely bad; pastures are scalding and feed is much wanted - the potatoes and turnips have an unhealthy appearance, the former past recovery - the spring crops may be a fair average if they receive sufficient moisture by the end of the week."

The impacts of droughts in agriculture are particularly reflected in crop yields. For example, documentary sources from the Czech Lands reported the following for 1842: weaker yields of barley and oats (the ears were sometimes so sparse and small that they had to be been harvested manually, without tools); wheat and rye yields were generally average depending on location; lack of straw, which was already short in the stem; failure of potatoes ("[potatoes] were the size of walnuts and almost inedible, [more like] overgrown peas"; Robek, 1978, p. 49); a meagre harvest of vegetables (peas, lentils, cabbages), flax, beet, vetch, and hops; unripe fruits fell from their trees early; it was impossible to plough, and stubble fields remained unturned after the harvest. There was a generally small yield of hay and no aftermath (i.e. the second hay growth). A report dated 1 September from Trieste (Italy) noted that all the plants had died and trees were even losing their leaves as if it were already autumn (Journal de Bruxelles, 15 September 1842). Further east, in the Košice area of Slovakia, cabbages and potatoes were in a poor state in the first days of September due to extended heat and outstanding drought (Nemzeti Újság, 10 September 1842); problems with the late development and a bad harvest of potatoes due to drought were also mentioned in Verôce and Miskolc in Hungary (Nemzeti Újság, 13 and 26 November 1842).

However, regional differences in yields could be quite marked. Records from Hungary (as then politically defined) indicate that the harvest of both winter and spring crops was weak, except in the most significant grain production areas in the southern and eastern parts of the Great Hungarian Plain, particularly the Bačka (north Serbia) and the Banat (north-eastern Serbia and south-western Romania) regions (Jelenkor, 3 September 1842). While rather bad cereal and hay harvests were reported in the northern part of the plain (e.g. Nemzeti Újság, 10 September 1842), reports from around Kecskemét in its central part indicate that maize, barley, and oat harvests were not good; chronicles kept by Franciscan monks suggest a lack of these crops, while remaining silent about other harvests in 1842 (Szabó, 1992). In the Bratislava area of Slovakia in late July, when harvesters' wages were fixed, the spring crops were particularly bad, while the winter crops showed little promise over large areas (Jelenkor, 30 July 1842). Moreover, in Šariš County (northeastern Slovakia), hail destroyed the harvests of more than 40 settlements (Jelenkor, 27 August 1842).

Yields of grain also suffered from a population explosion of mice and hamsters. Some villages in the Mainz region (Germany) were driven to pay bounty on them. Similar overpopulation problems were reported for other regions 
of Germany, such as the Rhine region, Saxony, Thuringia, and Lower Franconia (Beyer, 1843), but damage done by an overabundance of rodents was also reported in Hungarian Szekszárd (Nemzeti Újság, 19 October 1842). In Auchterarder (Scotland), farmers lived in fear of "myriads of small white worms" which were capable of damaging all kinds of vegetables in time of drought (The Morning Chronicle, 23 June 1842, p. 6). Another interesting manifestation of insect overpopulation was reported from the Netherlands, where farmers in some places were unable to plough their fields in the face of a drought-facilitated multitude of wasps' nests (Nederlandsche Staatscourant, 18 August 1842). In Neuchâtel, Switzerland, warnings appeared in September of the potential for overpopulation of wasps (due to the warm, dry summer) with respect to the damage that they might do to grapes (Wiener Zeitung, 20 September 1842).

In contrast to their negative influence on many other agricultural crops, high temperatures with drier patterns may prove positive to the quality of wine. Reports from Alsace (France) indicate that the grapes had to be picked and the soil bored in the dry times which lasted from mid-January to August. The cultivators had to use wedge-shaped hoes to split and pulverize soil so hard that it often damaged the tools. Because the vines themselves and other crops suffered heavily from the drought, the harvest was mediocre, or worse, in quantity; however, the wine was of excellent quality (Liblin, 1872). Beyond France, wine of excellent quality was also reported from other European countries such as Bohemia (Katzerowsky, 1895) and Moravia (Drössler, 1933). Generally ample harvests of grapes were also reported in Hungary (e.g. in Veszprém, Budapest; Nemzeti Újság, 19 October and 8 November 1842), but in most areas this held true for quantity rather than quality. Hailstorms, cold winds, and a rainy period from mid-September onwards were blamed for the medium quality in most places (e.g. Eger, Kőszeg, Verôce, Nagykálló, or Zemplín in Slovakia).

\subsubsection{Socio-economic drought}

The problems with lack of water described in Sect. 4.3.1 and 4.3.2 also found reflections in socio-economic matters. That more frequent fires were reported for 1842 in several documentary sources is testimony to such negative effects. A catastrophic example may be found in the Große Brand ("Great Fire") of Hamburg. After several weeks of extreme drought, fire broke out on 5 May at 01:00 LT (local time) which "took until the morning of 8 May to extinguish" (for a detailed description, see Schleiden, 1843). As Germany's most serious peacetime fire in modern history, it destroyed a third of the old town, with 72 streets, around 1100 houses, and 102 granaries. There were 51 fatalities, 120 people were injured, and 19995 people were made homeless (Hamburger Feuerwehr-Historiker E. V., 2005). An account of a fire in Rzeszów (Poland) on the night 26/27 June notes: "there was no rain for many days and roofs were so dry that each spark could lead to a devastating fire" (Wiener Zeitung, 10 July 1842, p. 1413). Lack of water complicated firefighting. For example, during a fire that broke out on 14 June in Zlončice in Bohemia, wells held so little water that people could only stand by and watch the conflagration with no means of extinguishing it (Robek, 1958a); a similar situation occurred during a fire on 23 August in Králova Lhota (Robek, 1978). In Austria, fire broke out on 17 July in Korneuburg; what water remained in the wells after a long, dry, and warm period was soon exhausted and three small lakes nearby were of little help (Wiener Zeitung, 21 July 1842).

The year 1842 also stands out in records of forest fires from many sources. For example, in the Branná domain (the Moravian part of Silesia), fire broke out on 17 August in the Liechtenstein Forest, burning for several days at the expense of over 2000 fathoms (ca. $5680 \mathrm{~m}^{3}$ ) of timber; it had still not been extinguished on 26 August (Diekircher Wochenblatt, 10 September 1842). Blase (1845) reported in great detail a forest fire that started on 31 August in "SaxonBohemian Switzerland" and went on to destroy a forest area of 327 "Acker" (ca. 181 ha), of which 172 "Acker" were on the Saxon side and 155 on the Bohemian side (ca. 95.2 and 85.8 ha, respectively). A number of reports of August forest fires also appear for Norway (e.g. Münchner politische Zeitung, 26 August 1842; Wiener Zeitung, 15 September 1842).

A general idea of the statistical scale of city and forest fires occurring in the generally driest period of AprilSeptember 1842 may be obtained if reports appearing only in Wiener Zeitung are considered. These indicate a total of 68 concrete cases of fire elsewhere in Europe nevertheless considered newsworthy by an Austrian newspaper (in Austria, Belgium, the Czech Lands, Germany, Hungary, France, Italy, the Netherlands, Norway, Poland, Romania, Russia, Sweden, and England). Nine of the stories explicitly mention drought or lack of water. Moreover, in addition to such precisely localized fires, more general statements about further fires in the given region or country also appear (for example, a despatch from Paris, dated 28 September, makes wider mention of daily fires in the Seine-et-Marne region; see Wiener Zeitung, 7 October 1842).

The general lack of water (Sect. 4.3.1) had many further consequences. Water mills unable to operate led to a lack of flour for baking bread with inevitable shortages and consequent price rises. Lack of milling capacity meant that the grist was ground rough rather than finer milled to flour. An attempt at using man-power to turn the mills in Saxony employed 8-10 men, who managed to grind one "Dresdner Viertel" (ca. 27 L of grain) in $2 \mathrm{~h}$ (Beyer, 1843). The Dresden administration sent steam engines to its two most important mills and horse-powered gins to several others (Wiener Zeitung, 18 September 1842). Citing the acute lack of flour, Vincenz Rohn in Litoměřice (Bohemia) obtained permission to build a steam mill there (Katzerowsky, 1895). In Aachen (Germany) and neighbouring parts of Belgium, weaving fac- 
tories were limited by water shortage and human power was used to maintain at least part of their production (Allgemeine Preußische Staats-Zeitung, 22 July 1842).

Dried-up water sources were also indicated by military records in that they were cited as reasons for the cancellation of manoeuvres, as reported on 20 August from Berlin in Germany (Wiener Zeitung, 3 September 1842, p. 1807): "[due to] incessant heat and a considerable shortage of water, $[\ldots]$ the consequences of a winter without snow and of a dry spring [... ] wells and small lakes are entirely dry at a majority of settlements and people are having to bring water from great distances. [This indicates] that the cavalry can expect to find no watering places; [since water] would have to be made available at campsites, manoeuvres were completely cancelled on the evening before muster." Similarly, a report from Düsseldorf a day earlier mentioned that if the very hot and dry weather conditions did not change, then the military manoeuvres already taking place would be significantly curtailed (Wiener Zeitung, 26 August 1842).

The problems associated with lack of water impact upon animals as well as people. For example, the "Book of Memory" for Heřmanovice (northern Moravia) reports that coachmen took containers of water for their horses from Bohemia to Silesia because most of the wells and streams there were dry (AS3). On 15 June, people in Emden (Germany) gave voice to a host of complaints about a lack of water. The ports and waterways had to be flushed with seawater, so all the city canals in their neighbourhood had become salty and therefore useless for cattle or irrigating the vegetable gardens around the city (Algemeen Handelsblad, 26 June 1842).

Small yields of hay and no aftermath (Sect. 4.3.2) led to a critical situation for those who raised cattle. A desperate lack of forage meant that farmers were forced to sell off livestock at prices deeply below the normal market rates or to slaughter livestock for meat. In some cases, livestock numbers dropped to a half or even a third of previous numbers. This was especially true of cattle and sheep. Although, whenever possible, farmers found substitute forage (e.g. vetch, tree foliage), the immediate market effects were substantial. For example, the records kept by Václav Křeček from Dobruška (Bohemia) note (Robek, 1978, pp. 49-50): “a cow, which was [worth] 100 gulden a year ago, went [in 1842] for 40 or 50 gulden, and it was not possible to sell [a cow] to anyone because of too little fodder. A two-year heifer could be bought for 20 gulden, maximally 25 gulden, while a year ago [the price for such a beast] was 50, or even as much as 60 gulden. [...] Older cows could be bought for 25 or 30 gulden." In the former Hungarian domain of Levoča (now Slovakia), an irrigation system for meadows and gardens was introduced in 1842 in an attempt to alleviate any future droughts (Érkövy, 1863; see also Magyar Gazda, 24 November 1842).

Town and city administrations were also obliged to address the critical scarcity of water. For example, on 6 June, the council of the city of Bruges (Belgium) forbade the washing or cleaning of the streets, pavements, houses, and windows "until further notice" (Gazette van Brugge, 6 June 1842, p. 2). The mayor and municipal executive of the city of Middelburg, Zeeland in the Netherlands, in consideration of the most economical use of the water, decided to forbid sanding the streets, the pavements, and houses, and the washing of windows (Middelburgsche Courant, $11 \mathrm{Au}-$ gust 1842). In Haarlem (the Netherlands), it was announced on 19 August that the city and neighbourhood pumps will remain closed at night and would be opened for only 2 hours a day for residents. The inhabitants were furthermore enjoined to use water sparingly and to use it as little as possible to rinse and scrub the streets and pavements (Algemeen Handelsblad, 22 August 1842).

The governor of the province of West Flanders (Belgium) adopted quite drastic measures to conserve water. He imposed restrictions on the use of the locks on the river Yser and its associated canals. In particular, in consideration of petitions from local authorities concerned at the scarcity of water in the interior, the usual drainage and flushing of the canals was to be delayed from 1 until 20 September (Gazette van Brugge, 17 and 24 August 1842).

To minimize the danger of fire during prolonged dry weather, the mayor and municipal executive of the city of Rotterdam (the Netherlands) decided that any pyrotechnics, such as aerial candle lanterns, flares, or fireworks, would not be permitted (Rotterdamsche Courant, 9 August 1842). On 17 August, the equivalent city authorities in The Hague decided, bearing in mind the catastrophic consequences of a possible fire, to prevent many city pumps providing sufficient water for scrubbing the streets and similar work (Dagblad van 's Gravenhage, 19 August 1842). Reported in Hungarian Szeged, smoking a pipe was not permitted due to the heat and drought (Reizner, 1899).

There was an interesting consequence of the 1842 drought in the southern part of the basin of Ferto/Neusiedl in Hungary. Low water levels allowed archaeological explorations that resulted in new "prehistoric" findings in the temporarily dry part of its extensive shallow lake basin (Élő, 1937).

Great heat and drought, particularly in August 1842, contributed to certain illnesses, particularly respiratory but also including fevers and malaria, as described by the local medical officer in Uzhhorod (Ukraine) in the former Hungarian county of Ung (see Sect. 2.1, point vi).

Social reflections of the 1842 drought may be found in practices of religious institutions such as the organization of masses, prayers, and formal public processions to entreat God for rain. For example, from Munich (Germany) on 2 July, regular processions of entreaty for rain are reported from the countryside, as well as one planned also in town in the coming days (Allgemeine Preußische StaatsZeitung, 8 July 1842). On 17 June and on 18 August, the bishop of Bruges (Belgium) decreed prayers for rain (Middelburgsche Courant, 18 June 1842; Gazette van Brugge, 19 August 1842). In Antwerp (Belgium), public prayers started on 26 August in all the city's churches, although some 
rain had fallen, because the drought remained "fearful" for people and animals. In the neighbourhood of Zandhoven, it was decided that houses should no longer be sanded for fear of shortage of drinking water, as all the wells were dry (Gazette van Brugge, 29 August 1842). In Hostín, Bohemia, Josef Vorlíček reported frequent masses and prayers for rain, as well as the occasional procession of entreaty in 1842 , but he thought "that God has blocked his ears and does not hear our voice" (Robek, 1958b, p. IV/28). Considerably more curious was an explanation offered for the lack of rain in the Mladá Boleslav region (Bohemia): "It is said that it is not raining because the last time someone died in Plasy, they put a little down blanket under the dear departed's head and said that if the feathers did not rot, it would not rain" (Kamper, 1927-1928, p. 247).

More seriously, the drought of 1842 was considered a consequence of the solar eclipse of 8 July (e.g. Heisig, 1929). This led Franz von Paula Gruithuisen (1774-1852), professor of medicine and astronomy in Munich (Germany), to a statement in Münchner politische Zeitung on $2 \mathrm{July}$, in which, based on an analogy with the drought of 1811, he associated the extreme drought of 1842 with a lack of sunspots: "There is very widespread opinion that the imminent solar eclipse [8 July] is responsible for the great drought of the current spring and summer. Being more closely acquainted with the influence of the Sun on the Earth, I may assert firmly that the recent drought is related to a striking lack of sunspots. The recent weather is similar to that of the year 1811, in which the same [degree of] drought and the same lack of the sunspots that usually tend to herald steady weather, occurred, when the same [degree of] drought, the same state of the grain and the same splendid growth of grapes [were observed]" (Österreichischer Beobachter, 5 July 1842, p. 723). A full solar eclipse was so impressive that in the French L'Écho de la Frontière, reporting for Valenciennes (1 and 2 August 1842, p. 1) appears: "the year 1842 will be classified among the numbers of years of abundance of all kinds, together with its good wine [which], if The Lord deigns so to do, may be called 'the wine of the eclipse', [just] as that of 1811 was named the 'wine of the comet' [Flaugergues' comet]".

\section{Discussion}

\subsection{The 1842 drought in the longer-term context}

Starting at the western part of the territories analysed herein (Fig. 3), Slonosky (2002) identified 1842 as the tenth driest year in the homogenized precipitation series for Paris in the $1688-2000$ period. With its annual total of only $401 \mathrm{~mm}$, it was the second driest year of the 19th century, a little behind $387 \mathrm{~mm}$ in 1884. According to seasonal and annual precipitation totals reconstructed from documentary-based indices for the Czech Lands in the 1501-2010 period (Dobrovolný et al., 2015), the 1842 JJA precipitation was the second driest season (just behind the extraordinary year of 1540).
The same was found for annual precipitation. Furthermore, documentary-based indices rank 1842 as the driest spring (MAM) in the 1501-1854 period (together with 1571, 1638, 1683,1779 , and 1790).

In the context of instrumental series, April-September 1842 was the most extreme drought in the Czech Lands in the 1805-2012 period according to SPI-1, while it was the third worst in terms of $\mathrm{Z}$ index and the fourth most severe according to SPEI-1 (Brázdil and Trnka, 2015). Drought chronology created by a combination of documentary and instrumental data indicates that, for JJA as well as for the summer halfyear (April-September), the drought of 1842 had a return period of 200 years for SPI and 50 years for SPEI and Z index (Brázdil et al., 2019a). The reason for the difference between the 1842 drought rankings based on SPI on the one hand and SPEI with $\mathrm{Z}$ index on the other may easily be elucidated by reference to Fig. 5. While precipitation anomalies are present at almost every station (and are reflected in very low SPI values), above average temperatures, which would result in higher potential evapotranspiration and therefore drive SPEI and $\mathrm{Z}$ index values to negative values, occur only during certain months. As a result, SPEI and Z index rankings do not reflect the same gravity of drought as that seen through the lens of SPI. The summer of 1842 was the second-driest event according to scPDSI (sc - self-calibrated) in the north-east subregion of the Greater Alpine Region during the 18002003 period (van der Schrier et al., 2007). Inglot (1968) reported the MAM-JJA drought of 1842 as among the most important droughts in Lower Silesia. A report from Tallinn, in Estonia, dating to 15 September 1842, speaks of a sudden onset of mild autumn weather following on from periods of extraordinary heat and continual drought (Tarand et al., 2013).

Ogrin (2002), in a contribution addressing droughts in the Primorsko region of south-west Slovenia, reported severe drought from July to September 1841 (Trieste) and in August-September 1842; August-September 1843 were also dry. This tallies with historical records from neighbouring Hungary, where droughts were also reported for these 3 years (with catastrophic hay harvests and bad harvests of most crops, especially in 1841).

In eastern Europe, Russian annals reported drought ( $z a$ sucha) occurring in some regions and bad harvests in the Yekaterinburg, Tavrida, Pskov, Mogilev, Podolsk, Vitebsk, and Perm districts. However, a wet summer was reported in the Stavropol region and only August was dry with clear skies. Locust plagues occurred, particularly in the Poltava and Chernigov regions (Borisenkov and Pasetskiy, 1988). In Europe, a report dated 10 May mentions the first swarms of locusts in the province of Messinia (Greece) but they were destroyed by the inhabitants under the direction of the authorities. However, more swarms followed and a part of the yield was destroyed (Journal des débats politiques et littéraires, 6 June 1842). 
Reports of locusts or over-reproduction of some insects or small mammals (Sect. 4.3.2) in association with drought do not necessarily mean that such trends among animals are exclusively the consequences of drought. However, there is a higher probability of their occurrence. Excesses of pests (i.e. insects, rodents, and other small mammals) usually increase during droughts (e.g. Yihdego, 2018), although this relationship is not always consistent (e.g. Maxmen, 2013). A clear association has been established between hydrological extremes (including drought) and mice (or other rodent) pests (e.g. Pech et al., 1999). Wasps become more active and lay far more eggs at times of drought and/or warm weather (Romo and Tylianakis, 2013). Drought is also a very important stimulating factor for locusts to develop into their highly social gregarious form and phase, leading to higher activity and mass movements (e.g. Rogers and Ott, 2015).

\subsection{Reflections of the 1842 drought in tree rings and phenophases}

Many tree rings in Europe are sensitive to hydroclimatic conditions; it permits the reconstruction of drought patterns (PAGES Hydro2k Consortium, 2017). According to the Old World Drought Atlas (OWDA; Cook et al., 2015), summer scPDSI values derived from tree-ring widths (TRWs) in Europe (Fig. 10) demonstrate dry patterns for 1842, especially in two south-west to north-east belts: the first over western Europe from south-western France to the North Sea (quite intense drought) and the second located more to the east, from the Adriatic Sea to south-eastern Poland and western Ukraine. The northern and western parts of the Iberian Peninsula, a greater part of the British Isles, and a part of western Russia also appear dry.

Among individual hydroclimate reconstructions based on TRWs, the year 1842 appears as the 11th driest in terms of May-June $\mathrm{Z}$ index derived from living and historical firs (Abies alba Mill.) in South Moravia during the 1500-2007 period (Büntgen et al., 2011a). On the other hand, 1842 does not appear among extremes of the fir TRWs sensitive to springtime hydroclimate in the 962-2007 period derived from 11873 samples from France, Germany, Switzerland, and the Czech Lands (Büntgen et al., 2011b). It is also absent, for example, from the 20 most negative JJA scPDSIs reconstructed for 1744-2006 from 86 pine (Pinus sylvestris) TRWs in northern Slovakia (Büntgen et al., 2010).

Droughts, often accompanied by high temperatures, may influence the onset of certain phenophases, bringing them on early. For example, in a report from the Bergstraße (an ancient, ca. $80 \mathrm{~km}$ long trade route in south-western Germany), dated 12 June 1842 reads: "Our vineyards are in full bloom; all will have finished in 8 to $10 \mathrm{~d}$ and so in 1842 a rare occasion will arise, that the grape blossoms are over before Saint John's [24 June]" (Arnhemse Courant, 19 June 1842, p. 2). In the vineyards of Köszeg (Hungary), the grapes started to ripen more than 2 weeks earlier than usual; however, when
Table 1. Saturday's market prices of wheat (Metzen, $51.487 \mathrm{~L}$ ), hay (Zentner, $56.006 \mathrm{~kg}$ ), and straw (60 shocks) in Opava (Moravian Silesia) on selected dates during 1842 and 1843. Prices are expressed in gulden (Florin, fl.) and kreutzer (Kreutzer, kr.) of Vienna currency. Source of data: Troppauer Zeitung.

\begin{tabular}{lrr|rr|rr}
\hline & \multicolumn{2}{c|}{ Wheat } & \multicolumn{2}{c|}{ Hay } & \multicolumn{2}{c}{ Straw } \\
\cline { 2 - 7 } Date & fl. & kr. & fl. & kr. & fl. & kr. \\
\hline 26 March 1842 & 7 & 48 & 2 & 15 & 12 & 0 \\
28 May 1842 & 8 & 27 & 2 & 24 & 13 & 30 \\
18 June 1842 & 8 & 42 & 2 & 24 & 14 & 0 \\
30 July 1842 & 8 & 57 & 3 & 6 & 15 & 30 \\
27 August 1842 & 7 & 0 & 4 & 24 & 16 & 0 \\
1 October 1842 & 6 & 48 & 4 & 15 & 15 & 0 \\
26 November 1842 & 6 & 6 & 4 & 12 & 16 & 0 \\
14 January 1843 & 5 & 57 & 4 & 9 & 16 & 0 \\
25 February 1843 & 5 & 54 & 3 & 57 & 14 & 30 \\
15 April 1843 & 5 & 48 & 3 & 39 & 15 & 0 \\
1 July 1843 & 6 & 33 & 3 & 18 & 15 & 15 \\
23 September 1843 & 8 & 12 & 1 & 57 & 9 & - \\
\hline
\end{tabular}

the time came to harvest them in October, they were only $3 \mathrm{~d}$ earlier than usual (Kiss et al., 2011). In the neighbouring town of Szombathely the grape harvest was forced by copious rain to start earlier than planned (5 October). This also affected the quality of the wine as it probably did in Köszeg as well, located only ca. $20 \mathrm{~km}$ from Szombathely (AS4). Brázdil et al. (2011) disclosed that early onset of ripeness in sour cherry (Prunus cerasus), common blackthorn (Prunus spinosa), and blackheart (Vaccinium myrtillus) took place in 1842 at the Hradec Králové station (Bohemia) relative to the 1828-1847 period. Moreover, Brázdil et al. (2019b) showed that air temperatures combined with drought effects (expressed by SPEI) played a significant role in series of cropand grape-harvest dates in the Czech Lands in the 1517$1542,1561-1622,1770-1815$, and 1971-2010 periods; only in the generally wet period of 1871-1910 was any significant effect of SPEI absent.

\subsection{The impacts of the 1842 drought in a broader context}

Depending on the part of the year in which dry spells appear, changes in the prices of agricultural products and goods may be indicators of the effects of bad harvests, despite the many other influences upon them (e.g. damage due to other weather extremes, projected grain yields, export and import of grain, reserves, frequency of grain markets, wars, administrative decrees, and financial speculation; Petráň, 1977).

The influence of drought on the prices of agricultural crops may be best expressed from prices within the year in question, or the one following it. For example, the Saturday market prices for Opava (Moravian Silesia) were published in Troppauer Zeitung. Despite a relatively high number of 
TREE-RING RECONSTRUCTED DROUGHT 1842

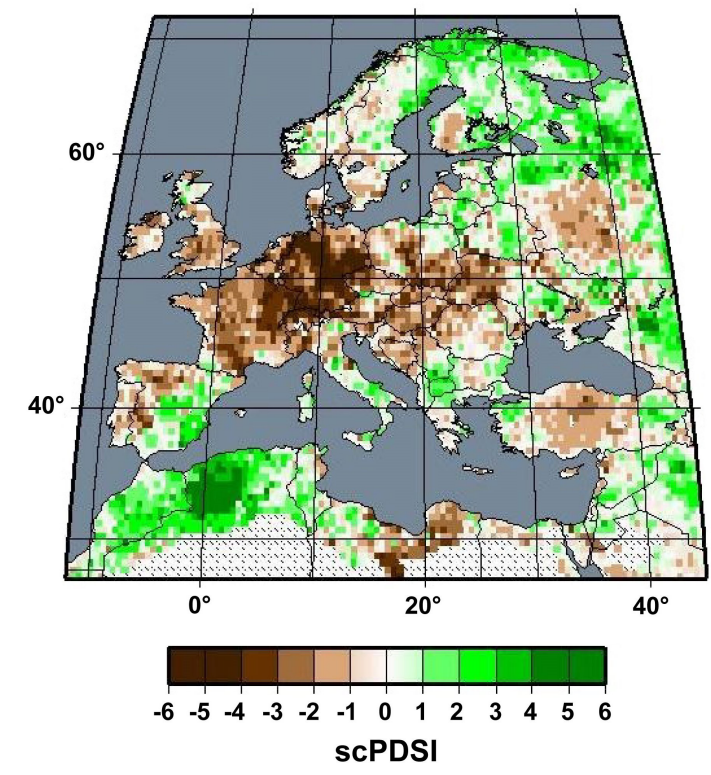

Figure 10. Values of summer scPDSI for 1842 in the European area as derived from tree rings in OWDA (Cook et al., 2015).

missing values, considerable influence of the drought upon the prices of wheat, hay, and straw resulting from the 1842 drought is well expressed (Table 1). An increase in wheat prices (expressed in gulden or florins (fl.) and kreutzer (kr.)) from spring to harvest time (by ca. $1 \mathrm{fl}$. from $7 \mathrm{fl}$. $48 \mathrm{kr}$.) was probably partly related to fear of lower yields due to drought, but these eventually proved less negatively affected, i.e. prices started to decline after harvest (down to as low as $5 \mathrm{fl} .48 \mathrm{kr}$. in April 1843). Prices of hay ( $2 \mathrm{fl} .15 \mathrm{kr}$. at the end of March 1842) rose steadily after a poor haymaking, and then more sharply after failure of the aftermath. From August 1842 onwards, hay prices remained constantly over $4 \mathrm{fl}$., dropping slightly below this value only at the end of February 1843. After a steady decrease to $3 \mathrm{fl}$. in August 1843, prices suddenly dipped slightly below $2 \mathrm{fl}$. in the following month as a result of a good haymaking. The dry conditions in 1842 resulted in lower quantities of straw than usual. This was reflected in a price increase from $12 \mathrm{fl}$. at the end of March 1842 to $16 \mathrm{fl}$. at the end of August. Straw prices fell significantly after the 1843 harvest to as low as $8 \mathrm{fl} .30 \mathrm{kr}$. in October 1843 (not shown in Table 1).

In the longer term, the effects of the 1842 drought appear relatively negligible. This is evident, for example, in overall grain production in the Czech Lands, which documentation indicates was not very strongly influenced by the drought (see Sect. 4.3.2). Figure 11 shows only a slight increase in the prices of basic cereals in Prague from a local minimum in 1841 through 1842, achieving a local maximum in 1843 during the $1832-1852$ period. However, far worse

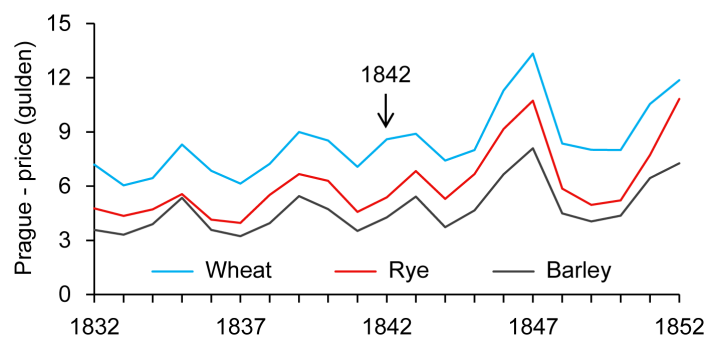

Figure 11. Fluctuations in grain prices (wheat, rye, barley) in Prague during the 1832-1852 period (data from Schebek, 1873).

increases in grain prices took place during 1846-1847, the result of very bad grain harvests in these 2 years, as recorded in many Czech documentary sources. Similarly, the market prices of agricultural products in Vienna in 1842 were often somewhat higher than in other years. However, only the prices of legumes (peas, beans, lentils) rose significantly, by $30 \%-40 \%$ over the previous and following years (see Pribram, 1938).

The fact that no particularly outstanding price increases for base products occurred in either Prague or Vienna could result from a number of factors and administrative strategies or decisions. One important influence was the mass storage of grain in royal or regional granaries; such a reserve could buffer the effects of at least one bad harvest (e.g. Jelenkor, 3 September 1842). In similar fashion to that described for Hungary, this factor was also present at that time in other countries investigated (e.g. France, Germany, the Czech Lands, Austria) which had, for example, granaries and a burgeoning trade in basic agricultural products. It was also significant that the official market prices of major food products (meat, cereals, etc.) were fixed by regional authorities. Despite actual market increases, these regulations may have had a positive impact and again could have buffered some of the immediate effects of the bad and very bad harvest results of a dry year (e.g. Nemzeti Újság, 18 September 1842). Moreover, not all regions were affected to the same degree by drought and related natural extremes. There were areas that saw ample harvests in 1842 within the vast and geographically varied Habsburg empire: for example, the major grain production regions of southern Hungary had a good harvest and its cereals were exported. Reports in the Jelenkor newspaper suggest regular shipping on the Danube towards Vienna all summer and autumn 1842, evidently not disturbed by low water levels. Further, despite less favourable (or even bad) hay harvests at country level, the export of hay from Hungary to Lower Austria (and Vienna) increased significantly in the dry years of 1841 and 1842; this may well have been due to the increased hay yields in the Fertö/Neusiedl and Hansag/Wasen wetlands during the dry years (Horváth, 2016).

According to the "Book of Memory" kept by the school in Hlinsko, great poverty and hunger afflicted many places 
in Bohemia, beginning in spring 1843 , due to the previous year's drought and consequent shortage of potatoes, which partly rotted in and after storage. Moreover, people lacked the money to buy those cereals and potatoes that were available. Direct financial support from the Vienna court and public subscriptions were organized in order to assist those who were suffering most, particularly in certain regions of Bohemia (e.g. the Krušné hory (Ore Mountains) and the Loket and Žatec regions). Emperor Ferdinand I also lent his support to building new roads and maintaining older ones, thus re-establishing some cash flow among the more deprived social classes (Adámek, 1908). That the situation was similarly critical on the German side of the Krušné hory (Erzgebirge) is evident in a record of the words of an unknown farmer, dated to 20 August 1842: "Since 1816 [the "Year without a Summer"], the very opposite of 1842 , no year has been so tormented with respect to agriculture [...] as this one [1842], and no other has been so horrible for me as the current [one]." (Ökonomische Neuigkeiten und Verhandlungen, p. 790). In contrast, it was important in historical Hungary and Transylvania that the 1842 drought occurred after the similarly dry, perhaps even more severe, year of 1841 , when shortages, or even famine, developed in those regions most severely afflicted, mainly areas with the worst harvests, on the one hand, and those intrinsically deprived and/or with transportation problems of bulk products on the other. Shortages and even famine were reported among the poor, and perhaps others, in Bihar, Nógrád, and Szabolcs counties in Hungary (e.g. Nemzeti Újság, 21 May and 30 July 1842; Jelenkor, 30 June 1842).

\section{Conclusions}

From this analysis of the 1842 drought in Europe (not including the Mediterranean), the following conclusions may be drawn:

i. Spatial reconstruction and measured totals indicate that precipitation was significantly reduced, particularly in a broad belt extending from France to eastern central Europe. Despite regional differences, dry patterns prevailed mainly in January-February and, with some regionally different degrees of intensity, between April and August.

ii. The 1842 drought was primarily driven by the precipitation anomaly and only to a far lesser extent exacerbated by an evapotranspiration demand that was higher than usual, as indicated by the three types of drought indices employed herein.

iii. Mean monthly SLP maps demonstrate the influence of anticyclones or ridges of high pressure upon the precipitation reduction in some areas. The relationships between monthly precipitation totals and circulation indices (NAOI and CEZI) proved rather complicated. iv. The general lack of water giving rise to the drought led to a range of impacts on agriculture, forestry, water infrastructure, and society at both personal and administrative levels, human responses to which varied. Impacts conveyed through documentary sources were generally more severe than might be expected from the drought extremity calculated from drought indices. However, societal responses managed to reduce possible negative impacts to acceptable levels and avoid further longerterm consequences.

v. The effects of the 1842 drought on vegetation derived from documentary data are also clearly reflected in JJA scPDSI reconstructed from TRWs in OWDA (Cook et al., 2015).

vi. This contribution confirms the importance of combining information from systematic meteorological (hydrological) measurements and documentary evidence for comprehensive description of any dry event, together with its spatio-temporal aspects, synoptic reasons, environmental and societal impacts, and human responses.

Data availability. The sources of basic datasets are quoted on the corresponding places of the paper. Other data used are available from the corresponding author.

Supplement. The supplement related to this article is available online at: https://doi.org/10.5194/cp-15-1861-2019-supplement.

Author contributions. RB designed and wrote the paper with contributions from all co-authors. AK contributed with data sources and drought impacts from former Hungary. PD analysed spatial distribution of precipitation and synoptic patterns. MT worked with drought indices. GD, KC, LD, and Ľ̌ contributed with drought reports from newspapers and other documentary sources, $\mathrm{PZ}$ with recent meteorological data for Prague-Klementinum, and DL and SJ with long-term meteorological series. KC and Ľ finalised the figures.

Competing interests. The authors declare that they have no conflict of interest.

Special issue statement. This article is part of the special issue "Droughts over centuries: what can documentary evidence tell us about drought variability, severity and human responses?". It is not associated with a conference.

Acknowledgements. Rudolf Brázdil, Petr Dobrovolný, and Lukáš Dolák acknowledge financial support from the Czech Science Foundation for project ref. 17-10026S. Miroslav Trnka, 
Ladislava Řezníčková, and Pavel Zahradníček were supported by the Ministry of Education, Youth and Sports of the Czech Republic for the SustES - Adaptation strategies for sustainable ecosystem services and food security under adverse environmental conditions, project no. CZ.02.1.01/0.0/0.0/16_019/0000797. Andrea Kiss would like to acknowledge financial support from the Austrian Science Funds project ref. I 3174. Jan Balek (Brno) is acknowledged for calculation of drought indices for Fig. 6; Neil Macdonald (Liverpool), Anders Moberg (Stockholm), Christian Rohr (Bern), and Victoria C. Slonosky (Montreal) are thanked for help with finding and obtaining instrumental meteorological series and adding further information. Tony Long (Svinošice) helped work up the English. We would also like to thank Gerard van der Schrier and the two other anonymous reviewers for their comments that helped significantly to improve the paper.

Financial support. This research has been supported by the Czech Science Foundation (grant no. 17-10026S), the Ministry of Education, Youth and Sports of the Czech Republic (project no. CZ.02.1.01/0.0/0.0/16_019/0000797), and the Austrian Science Funds (grant no. I 3174).

Review statement. This paper was edited by Stefan Grab and reviewed by Gerard van der Schrier and two anonymous referees.

\section{Archival sources}

[AS1] Csongrád County Archives, Archives of Szeged Town IV.B. 1017, Jegyző-Könyv A` Tisza Vize Tükrének I-số Januáriustól 31-ik Decemberig 1842-ik Esztendei állapotjáról (manuscript).

[AS2] Dagboek van Doeke Wijgers Hellema at Wurdum, Friesland, the Netherlands, http://www.erfgoed-fundaasje. nl/hellema/dagboeken-van-doeke-wijgers-hellema/ dagboek-16-1842/ (last access: 23 May 2019).

[AS3] Státní okresní archiv Bruntál, fond obce Heřmanovice, Pamětní kniha obce Heřmanovice.

[AS4] Vas County Archives, Vas megyei levéltár V/102a, Szombathely város tanács közgyúlési jegyző́könyvei (Meeting protocols of the council of Szombathely town).

\section{References}

Adámek, K. V.: Památní kniha školy hlinecké od roku 1833 (The "Book of Memory" kept by the school in Hlinsko, 1833 onwards), Zprávy Musea okresu hlineckého, 1, 27-40, 1908.

Allan, R. and Ansell, T.: A new globally complete monthly historical gridded mean sea level pressure dataset (HadSLP2): 1850-2004, J. Climate, 19, 5816-5842, https://doi.org/10.1175/JCLI3937.1, 2006.

Auer, I., Böhm, R., Jurkovic, A., Lipa, W., Orlik, A., Potzmann, R., Schöner, W., Ungersböck, M., Matulla, C., Briffa, K., Jones, P. D., Efthymiadis, D., Brunetti, M., Nanni, T., Maugeri, M., Mercalli, L., Mestre, O., Moisselin, J.-M., Begert, M., MüllerWestermeier, G., Kveton, V., Bochnicek, O., Stastny, P., Lapin,
M., Szalai, S., Szentimrey, T., Cegnar, T., Dolinar, M., GajicCapka, M., Zaninovic, K., Majstorovic, Z., and Nieplova, E.: HISTALP - Historical instrumental climatological surface time series of the greater Alpine region 1760-2003, Int. J. Climatol., 27, 17-46, https://doi.org/10.1002/joc.1377, 2007.

Belgrand: La Seine - Études hydrologiques - Régime de la pluie, des sources, des eaux courantes - Applications a l'agriculture, Dunod, Éditeur, Paris, 1872.

Bělínová, M. and Brázdil, R.: Meteorologická pozorování c. k. Vlastenecko-hospodářské společnosti v Čechách v letech 18171847 (Meteorological observations of I. R. Patriotic-Economic Society in Bohemia in the years 1817-1847), Meteorol. Zpr., 65, 13-22, 2012.

Berde, A.: Légtüneménytan (Atmospheric phenomena studies). Özvegy Barráné és Stein, Kolozsvár [Cluj-Napoca], 1847.

Beyer, M.: Futternoth- und Hülfsbuch. Eine Angabe der hülfreichsten, thunlichsten Mittel, Futtermangel auszugleichen und ihm vorzubeugen, so wie der stattgehabten Erfolge ihrer Anwendung. Nebst einer kurzen Dastellung der Wirkungen außerordentlicher Dürre zum Andenken an 1842, und beiläufigen Bemerkungen über Getreideausfuhr, Mühlenwesen und Mehlfabrication Deutschlands, Immanuel Müller, Leipzig, 1843.

Blase: Mitteilungen über den am 31. August 1842 in der sogenannten sächs. böhm. Schweiz entstandenen Waldbrand, in: Forstwirtschaftliches Jahrbuch herausgeben von der Königlich Sächsischen Akademie für Forst- und Landwirthe zu Tharand, Zweiter Band, Arnoldische Buchhandlung, Dresden und Leipzig, 12-24, 1845.

Borisenkov, Y. P. and Pasetskiy, V. M.: Tysyatcheletnaya letopis neobytchaynykh yavleniy prirody (A Thousand-year History of Unusual Natural Events), Mysl, Moskva, 1988.

Botár, I. and Károlyi, Z.: A Tisza szabályozása II. rész: 1879-1944 (The regulation of the River Tisza, Part 2: 1879-1944), Vízügyi Történeti Füzetek 4, VIZDOK, Budapest, 32, 1971.

Brázdil, R. and Trnka, M. (Eds.): Sucho v českých zemích: minulost, současnost, budoucnost (Droughts in the Czech Lands: Past, Present and Future), Centrum výzkumu globální změny Akademie věd České republiky, v.v.i., Brno, 2015.

Brázdil, R., Bělínová, M., and Rožnovský, J.: Phenological observations made by the I. R. Bohemian Patriotic-Economic Society, 1828-1847, Theor. Appl. Climatol., 105, 71-81, https://doi.org/10.1007/s00704-010-0373-9, 2011.

Brázdil, R., Dobrovolný, P., Trnka, M., Kotyza, O., Řezníčková, L., Valášek, H., Zahradníček, P., and Štěpánek, P.: Droughts in the Czech Lands, 1090-2012 AD, Clim. Past, 9, 1985-2002, https://doi.org/10.5194/cp-9-1985-2013, 2013.

Brázdil, R., Raška, P., Trnka, M., Zahradníček, P., Valášek, H., Dobrovolný, P., Řezníčková, L., Treml, P., and Stachoň, Z.: The Central European drought of 1947: causes and consequences, with particular reference to the Czech Lands, Clim. Res., 70, 161-178, https://doi.org/10.3354/cr01387, 2016.

Brázdil, R., Dobrovolný, P., Trnka, M., Řezníčková, L., Dolák, L., and Kotyza, O.: Extreme droughts and human responses to them: the Czech Lands in the pre-instrumental period, Clim. Past, 15, 1-24, https://doi.org/10.5194/cp-15-1-2019, 2019a.

Brázdil, R., Možný, M., Klír, T., Řezníčková, L., Trnka, M., Dobrovolný, P., and Kotyza, O.: Climate variability and changes in the agricultural cycle in the Czech Lands from the sixteenth 
century to the present, Theor. Appl. Climatol., 136, 553-573, https://doi.org/10.1007/s00704-018-2508-3, 2019b.

Büntgen, U., Brázdil, R., Frank, D., and Esper, J.: Three centuries of Slovakian drought dynamics, Clim. Dynam., 35, 315-329, https://doi.org/10.1007/s00382-009-0563-2, 2010.

Büntgen, U., Brázdil, R., Dobrovolný, P., Trnka, M., and Kyncl, T.: Five centuries of Southern Moravian drought variations revealed from living and historic tree rings, Theor. Appl. Climatol., 105, 167-180, https://doi.org/10.1007/s00704-010-0373-9, 2011a.

Büntgen, U., Brázdil, R., Heussner, K.-U., Hofmann, J., Kontic, R., Kyncl, T., Pfister, C., Chromá, K., and Tegel, W.: Combined dendro-documentary evidence of Central European hydroclimatic springtime extremes over the last millennium, Quaternary Sci. Rev., 30, 3947-3959, https://doi.org/10.1016/j.quascirev.2011.10.010, 2011 b.

Camenisch, C., Brázdil, R., Kiss, A., Pfister, C., Wetter, O., Rohr, C., Contino, A., and Retsö, D.: Extreme heats and droughts of 1473 and their impacts in Europe in context of the early 1470s, Reg. Environ. Change, accepted, 2019.

Cook, E. R., Seager, R., Kushnir, Y., Briffa, K. R., Büntgen, U., Frank, D., Krusic, P. J., Tegel, W., van der Schrier, G., AndreuHeyles, L., Bailie, M., Baittinger, C., Bleicher, N., Bonde, N., Brown, D., Carrer, M., Cooper, R., Čufar, K., Dittmar, C., Esper, J., Griggs, C., Gunnarson, B., Günther, B., Gutierrez, E., Haneca, K., Helama, S., Herzig, F., Heussner, K.-U., Hofmann, J., Janda, P., Kontic, R., Köse, N., Kyncl, T., Levanič, T., Linderholm, H., Manning, S., Melvin, T. M., Miles, D., Neuwirth, B., Nicolussi, K., Nola, P., Panayotov, M., Popa, I., Rothe, A., Seftigen, K., Seim, A., Svarva, H., Svoboda, M., Thun, T., Timonen, M., Touchan, R., Trotsiuk, V., Trouet, V., Walder, F., Ważny, T., Wilson, R., and Zang, C.: Old World megadroughts and pluvials during the Common Era, Sci. Adv., 1, e150061, https://doi.org/10.1126/sciadv.1500561, 2015.

Dobrovolný, P., Brázdil, R., Trnka, M., Kotyza, O., and Valášek, H.: Precipitation reconstruction for the Czech Lands, AD 1501-2010, Int. J. Climatol., 35, 1-14, https://doi.org/10.1002/joc.3957, 2015.

Dodds, S. F., Burnette, D. J., and Mock, C. J.: Historical accounts of the drought and hurricane season of 1860, in: Historical Climate Variability and Impacts in North America, edited by: DupignyGiroux, L.-A. and Mock, C. J., Springer Science+Business Media B.V., Dordrecht, Heidelberg, London, New York, 61-77, 2009.

Drössler, K.: Geschichte der Pardorfer Kirche, Heimatblatt für den Nikolsburger Bezirk, 1, 69-72, 1933.

Elleder, L.: The Hunger stones: a new source for more objective identification of historical droughts, EGU General Assembly, Vienna, Austria, 17-22 April 2016, EGU2016-14986, 2016.

Élő, D.: Sarród monográfiája (Monography of Sarród). Országos Széchenyi Szövetség, Budapest, 5, 1937.

Érkövy, A.: Az 1863. évi aszályosság a magyar Alföldön (The 1863 drought in the Hungarian Plain), Kozma Ny., 68, 1863.

Fink, A. H., Brücher, T., Krüger, A., Leckebusch, G. C., Pinto, J. G., and Ulbrich, U.: The 2003 European summer heatwaves and drought - synoptic diagnosis and impacts, Weather, 59, 209-216, https://doi.org/10.1256/wea.73.04, 2004.

Fuster: Des changements dans le climat de la France, Histoire de ses révolutions météorologiques, par le Docteur Fuster, Capelle, Paris, 1845.
Hamburger Feuerwehr-Historiker E. V.: Der "Große Brand" in Hamburg 1842, available at: http://www.feuerwehr-historiker.de (last access: 16 April 2019), 2005.

Hammerl, C., Lenhardt, W., Steinacker, R., and Steinhauser, P. (Eds.): Die Zentralanstalt für Meteorologie und Geodynamik 1851-2001, 150 Jahre Meteorologie und Geophysik in Österreich, Leykam Buchverlagsgesellschaft, Graz, 2001.

Hao, Z. X., Zheng, J. Y., Wu, G. F., Zhang, X. Z., and Ge, Q. S.: 1876-1878 severe drought in North China: Facts, impacts and climatic background, Chinese Sci. Bull., 55, 3001-3007, https://doi.org/10.1007/s11434-010-3243-z, 2010.

Heim, R. R.: A review of twentieth-century drought indices used in the United States, B. Am. Meteorol. Soc., 83, 1149-1165, 2002.

Heisig, F.: Olbersdorfer Denkwürdigkeiten. Dritter Band 1862 bis 1884, Selbstverlag des Herausgebers, Olbersdorf, 1929.

Hoerling, M., Eischeid, J., Kumar, A., Leung, R., Mariotti, A., Mo, K., Schubert, S., and Seager, R.: Causes and predictability of the 2012 Great Plains drought, B. Am. Meteorol. Soc., 95, 269-282, https://doi.org/10.1175/BAMS-D-13-00055.1, 2014.

Horváth, G. K.: Der Rahmen des bäuerlichen Handels im Wieselburger Komitat (Ungarn) in der ersten Hälfte des 19. Jahrhunderts. Modell der Kommerzialisierung einer west-ungarischen Region, in: Bauern als Händler, edited by: Konersmann, F. and Lorenzen-Schmidt, K.-J., Ökonomische Diversifizierung und soziale Differenzierung bäuerlicher Agrarproduzenten (15.-19. Jahrhundert), De Gruyter, Oldenburg, 160-178, 2016.

Inglot, S.: Zjawiska klimatyczno-meteorologiczne na Śląsku od XVI do polowy XIX wieku (Research on the occurrence of drought in Lower Silesia from the 16th century to the mid20th century), in: Z badań nad wpływem posuchy na rolnictwo na Dolnym Śląsku, edited by: Świętochowski, B., Prace Wrocławskiego Towarzystva Naukowego B 139, Wrocław, 9-48, 1968.

Jacobeit, J., Jönsson, P., Bärring, L., Beck, C., and Ekström, M.: Zonal indices for Europe 1780-1995 and running correlations with temperature, Clim. Change, 48, 219-241, https://doi.org/10.1023/A:1005619023045, 2001

Jones, P. D., Jónsson, T., and Wheeler, D.: Extension to the North Atlantic Oscillation using early instrumental pressure observations from Gibraltar and South-West Iceland, Int. J. Climatol., 17, 1433-1450, https://doi.org/10.1002/(SICI)10970088(19971115)17:13<1433::AID-JOC203>3.0.CO;2-P, 1997.

Kamper, Z.: Josefa Luňáka, měšťana mladoboleslavského "Historky boleslavské z let 1825-76" ("The Stories of Boleslav, 1825-76" by Josef Luňák, a burgher of Mladá Boleslav), Boleslavan, 2, 236-257, 1927-1928.

Katzerowsky, W.: Meteorologische Nachrichten aus den Archiven der Stadt Leitmeritz, Selbstverlage des Vefassers, Leitmeritz, 1895

Kiss, A.: Droughts and low water levels in late Medieval Hungary II: $1361,1439,1443-4,1455,1473,1480,1482,1502-3$, 1506: Documentary versus tree-ring (OWDA) evidence, J. Environ. Geogr., 10, 43-56, https://doi.org/10.1515/jengeo-20170012, 2017.

Kiss, A.: Anatomy of a great drought and dearth in late medieval Hungary. The "great drought" of (1506-)1507 and its multiannual socio-economic consequences in a (Central-)European context, Reg. Environ. Change, in review, 2019. 
Kiss, A. and Nikolić, Z.: Droughts, dry spells and low water levels in Medieval Hungary (and Croatia) I: The great droughts of 1362, 1474, 1479, 1494 and 1507, J. Environ. Geogr., 8, 11-22, https://doi.org/10.1515/jengeo-2015-0002, 2015.

Kiss, A., Wilson, R., and Bariska, I.: An experimental 392-year documentary-based multi proxy (vine and grain) reconstruction of May-July temperatures for Kőszeg, West-Hungary, Int. J. Biometeorol., 55, 595-611, https://doi.org/10.1007/s00484-0100367-4, 2011.

Kogan, F. and Guo, W.: Early twenty-first-century droughts during the warmest climate, Geomagnetics, Nat. Hazards Risk, 7, 127137, https://doi.org/10.1080/19475705.2013.878399, 2016.

Krolmus, W.: Kronika čili dějepis všech povodní posloupných let, suchých i mokrých, úrodných a neúrodných na obilí, ovoce a vína, hladů, morů a jiných pohrom v Království Českém (Chronicle or History of all Floods in Consecutive Years, Dry and Wet [Years], Fertile and Infertile [Years] for Grain, Fruit and Wine, Periods of Starvation, Plagues and other Disasters in the Kingdom of Bohemia), Karl Wetterl, Praha, 1845.

Laaha, G., Gauster, T., Tallaksen, L. M., Vidal, J.-P., Stahl, K., Prudhomme, C., Heudorfer, B., Vlnas, R., Ionita, M., Van Lanen, H. A. J., Adler, M.-J., Caillouet, L., Delus, C., Fendekova, M., Gailliez, S., Hannaford, J., Kingston, D., Van Loon, A. F., Mediero, L., Osuch, M., Romanowicz, R., Sauquet, E., Stagge, J. H., and Wong, W. K.: The European 2015 drought from a hydrological perspective, Hydrol. Earth Syst. Sci., 21, 3001-3024, https://doi.org/10.5194/hess-21-3001-2017, 2017.

Liblin, J.: Chronique du maréchal-ferrant Jean-Baptiste Hun, de Turckheim, 1273-1856, dans Revue d'Alsace, Fédération des sociétés d'histoire et d'archéologie d'Alsace, 1872.

Luterbacher, J., Schmutz, C., Gyalistras, D., Xoplaki, E., and Wanner, H.: Reconstruction of monthly NAO and EU indices back to AD 1675, Geophys. Res. Lett., 26, 2745-2748, https://doi.org/10.1029/1999GL900576, 1999.

Luterbacher, J., Xoplaki, E., Dietrich, D., Rickli, R., Jacobeit, J., Beck, C., Gyalistras, D., Schmutz, C., and Wanner, H.: Reconstruction of sea level pressure fields over the Eastern North Atlantic and Europe back to 1500, Clim. Dynam., 18, 545-561, https://doi.org/10.1007/s00382-001-0196-6, 2002.

McKee, T. B., Doesken, N. J., and Kleist, J.: The relationship of drought frequency and duration to time steps, in: Preprints, 8th Conference on Applied Climatology, Anaheim, 17-22 January, 179-184, 1993.

Maxmen, A.: The threat of insects to agriculture is set to increase as the planet warms. What action can we take to safeguard our crops?, Nature, 501, S15-S17, 2013.

Mishra, A. K. and Singh, V. P.: A review of drought concepts, J. Hydrol., 391, 202-216, https://doi.org/10.1016/j.jhydrol.2010.07.012, 2010.

Mitchell, T. D. and Jones, P. D.: An improved method of constructing a database of monthly climate observations and associated high-resolution grids, Int. J. Climatol., 25, 693-712, https://doi.org/10.1002/joc.1181, 2005.

Munzar, J.: Extreme droughts in Central Europe in the preinstrumental period, Morav. Geogr. Rep., 12, 13-23, 2004.

Neue Schriften der kaiserl. königl. patriotisch-ökonomischen Gesellschaft im Königreiche Böhmen, Neunten Band, Erstes Heft, Gottlieb Haase Söhne, Prag, 1845.
Novotný, J.: Dvě stoleté hydrologické řady průtokové na českých řekách (Two-hundred-year Hydrological Series of Discharges on Czech Rivers). Sborník prací Hydrometeorologického ústavu ČSSR 2, Praha, 1963.

Ogrin, D.: Dry and wet years in submediterranean Slovenia from the 14th to the mid-19th century, Acta Univ. Palacki. Olomuc., Fac. Rer. Nat. - Geographica, 37, 55-62, 2002.

PAGES Hydro2k Consortium: Comparing proxy and model estimates of hydroclimate variability and change over the Common Era, Clim. Past, 13, 1851-1900, https://doi.org/10.5194/cp-131851-2017, 2017.

Palmer, W. C.: Meteorological Drought, Office of Climatology Research Paper 45, U.S. Weather Bureau, Washington, 1965.

Palotay, M., Mindszenty, A., Kopecskó, K., and Poros, Z.: Az Ínségkő geológiája (Geology of the Dearth-stone), Földtani Közlöny, 142, 243-250, 2012.

Pauling, A., Luterbacher, J., Casty, C., and Wanner, H.: Five hundred years of gridded high-resolution precipitation reconstructions over Europe and the connection to large-scale circulation, Clim. Dynam., 26, 387-405, https://doi.org/10.1007/s00382005-0090-8, 2006.

Pech, R. P., Hood, G. M., Singleton, G. R., Salmon, E., Forrester, R. I., and Brown, P. R.: Models for predicting plagues of house mice (Mus domesticus) in Australia, in: Ecologically-based Management of Rodent Pests, edited by: Singleton, G. R., Hinds, L. A., Leirs, H., and Zhang, Z., Australian Centre for International Agricultural Research, Canberra, 81-112, 1999.

Petráň, J.: Ceny obilí a tržní okruhy v Čechách v 18. a počátkem 19. století (Grain prices and market cycles in Bohemia in the 18th century and at the beginning of the 19th century), Acta Universitatis Carolinae, Philosophica et historica, Studia historica, 17, 9-49, 1977.

Pfister, C.: The "Black Swan" of 1540. Aspects of a European megadrought, in: Climatic Change and Cultural Transition in Europe, edited by: Leggewie, K. and Mauelshagen, F., Leiden, Brill, 156-194, 2018.

Pfister, C., Weingartner, R., and Luterbacher, J.: Hydrological winter droughts over the last 450 years in the Upper Rhine basin: a methodological approach, Hydrol. Sci. J., 51, 966-985, https://doi.org/10.1623/hysj.51.5.966, 2006.

Pribram, A. F.: Materialien zur Geschichte der Preise und Löhne in Österreich, Band I. Carl Ueberreuters, Wien, 1938.

Reizner, J.: Szeged története. 2. kötet. A XVIII. század végétől az 1879. évi árvízig (History of Szeged. Vol. 2: From the end of the 18th century to the flood in 1879), Szeged Szab. Kir. Város Közössége, Szeged, 1899.

Réthly, A.: Időjárási események és elemi csapások Magyarországon 1801-1900. II. Kötet (Weather Events and Natural Disasters in Hungary 1801-1900. Vol. 2), Országos Meteorológiai Szolgálat, Budapest, 1999.

Robek, A.: Zápisky lidového kronikáře Antona Pejška ze Zlončic (Notes by the folk chronicler Anton Pejšek from Zlončice), Kralupský vlastivědný sešit, září 1958, III/32-III/40, 1958a.

Robek, A.: Zápisky chalupníka Josefa Vorlíčka z Hostína (Notes by the Cottager Josef Vorlíček from Hostín), Kralupský vlastivědný sborník, ř́ijen 1958, IV/21-IV/34, 1958 b.

Robek, A.: Městské lidové kronikářství na Rychnovsku I. Edice lidových kronikářských textů (Town Folk Chronicle Writing of the 
Rychnov Region I. Edition of the Texts of Folk Chronicles), Ústav pro etnografii a folkloristiku ČSAV, Praha, 1976.

Robek, A.: Městské lidové kronikářství na Rychnovsku II. Edice lidových kronikářských textů (Town Folk Chronicle Writing of the Rychnov Region II. Edition of the Texts of Folk Chronicles), Ústav pro etnografii a folkloristiku ČSAV, Praha, 1978.

Rogers, M. S. and Ott, S. R.: Differential activation of serotonergic neurons during short- and long-term gregarization of desert locusts, P. Roy. Soc. B, 282, 20142062, https://doi.org/10.1098/rspb.2014.2062, 2015.

Roggenkamp, T. and Herget, J.: An extreme drought in the year $69 \mathrm{AD}$ on Lower Rhine. A quantitative reconstruction, Z. Geomorph., 59, 99-109, https://doi.org/10.1127/zfg_suppl/2015/S59205, 2015.

Romo, C. M. and Tylianakis, J. M.: Elevated temperature and drought interact to reduce parasitoid effectiveness in suppressing hosts, PLoS ONE, 8, e58136, https://doi.org/10.1371/journal.pone.0058136, 2013.

Schebek, E. (Ed.): Die Getreidepreise zu Prag 1655 bis 1872, in: Collectiv-Austellung von Beiträgen zur Geschichte der Preise veranstaltet zur Welt-Ausstellung 1873 Wien von der Handelsund Gewerbekammer in Prag, Katalog, Heinr. Mercy, Prag, 91104,1873

Schleiden, H.: Versuch einer Geschichte des großes Brandes in Hamburg vom 5. bis 8. Mai 1842. Auch als erläuternde Zugabe zu den 14 Speckter'schen Lithographien und dem Panorama, Mit einem Plane des Brandes in seinem Fortschritt von 6 zu 6 Stunden, Hoffmaan und Campe, Hamburg, 1843.

Shmakin, A. B., Chernavskaya, M. M., and Popova, V. V.: "Velikaya" zasucha 2010 g. na Vostochno-Evropeyskoy Ravnine: istoricheskiye analogi, cirkulyacionnyye mekhanismy (Great drought of 2010 in Eastern-European plain: Historical analogues, circulation mechnisms), Izvestiya RAN - Ser. Geogr., 6, 41-57, 2013.

Slonosky, V. C.: Wet winters, dry summers? Three centuries of precipitation data from Paris, Geophys. Res. Lett., 29, 1895, https://doi.org/10.1029/2001GL014302, 2002.

Société nationale d'horticulture de Paris: Observations météorologiques et horticoles recueillies à Villiers par $\mathrm{M}$. Jacques, Annales de la Société Royale d'Horticulture de Paris 30, Paris, 1842.

Spinoni, J., Naumann, G., Vogt, J. V., and Barbosa, P.: The biggest drought events in Europe from 1950 to 2012, J. Hydrol. Reg. Stud., 3, 509-524, https://doi.org/10.1016/j.ejrh.2015.01.001, 2015.

Squintu, A. A., van der Schrier, G., Brugnara, Y., and Klein Tank, A.: Homogenization of daily temperature series in the European Climate Assessment \& Dataset, Int. J. Climatol., 39, 1243-1261, https://doi.org/10.1002/joc.5874, 2019a.

Squintu, A. A., van der Schrier, G., van den Besselaar, E. J. M., Cornes, R., and Klein Tank, A. M. G.: Building long and homogenous temperature series in ECA\&D: blending of neighbour series, J. Appl. Meteorol. Clim., in review, 2019b.

Szabó, A.: Helytörténeti részletek a Kecskeméti Ferences Rendház háztörténetéből 1644-1950 (Local history excerpts from the Historia Domus of the Franciscan Friary in Kecskemét), BácsKiskun megyei levéltári füzetek 6, Megyei Levéltár, Kecskemét, 110, 1992
Szaplonczay, M.: A Balaton (Lake Balaton), in: Magyarország vármegyéi és városai, edited by: Csánki, D., Somogy megye, MTA, Budapest, 21-29, 1914.

Szewczuk, J.: Kronika klęsk elementarnych w Galicji, 1772-1848 (Chronicle of Elemental Phenomena in Galicia, 1772-1848), Badania z dziejów społecznych i gospodarczych 35, Lwów, 1939.

Tarand, A., Jaagus, J., and Kallis, A.: Eesti kliima minevikus ja tänapäeval (Estonian Climate: Past and Present), Tartu Ülikool, Kirjastus, 2013.

Uhe, P., Sjoukje, P., Kew, S., Shah, K., Kimutai, J., Mwangi, E., Van Oldenborgh, G. J., Singh, R., Arrighi, J., Jjemba, E., Cullen, H., and Otto, F.: Attributing drivers of the 2016 Kenyan drought, Int. J. Climatol., 38, 554-568, https://doi.org/10.1002/joc.5389, 2018.

van der Schrier, G., Efthymiadis, D., Briffa, K. R., and Jones, P. D.: European Alpine moisture variability 1800-2003, Int. J. Climatol., 27, 415-427, https://doi.org/10.1002/joc.1411, 2007.

Van Loon, A. F., Gleeson, T., Clark, J., Van Dijk, A. I. J. M., Stahl, K., Hannaford, J., Di Baldassarre, J., Teuling, A. J., Tallaksen, L. M., Uijlenhoet, R., Hannah, D. M., Sheffield, J., Svoboda, M., Verberein, B., Wagener, T., Rangecroft, S., Wanders, N., and Van Lanen, H. A. J.: Drought in the Anthropocene, Nat. Geosci., 9, 89-91, https://doi.org/10.1038/ngeo2646, 2016a.

Van Loon, A. F., Stahl, K., Di Baldassarre, G., Clark, J., Rangecroft, S., Wanders, N., Gleeson, T., Van Dijk, A. I. J. M., Tallaksen, L. M., Hannaford, J., Uijlenhoet, R., Teuling, A. J., Hannah, D. M., Sheffield, J., Svoboda, M., Verbeiren, B., Wagener, T., and Van Lanen, H. A. J.: Drought in a humanmodified world: reframing drought definitions, understanding, and analysis approaches, Hydrol. Earth Syst. Sci., 20, 36313650, https://doi.org/10.5194/hess-20-3631-2016, 2016 b.

Vicente-Serrano, S. M., Beguería, S., and López-Moreno, J. I.: A multi-scalar drought index sensitive to global warming: The Standardized Precipitation Evapotranspiration Index - SPEI, J. Climate, 23, 1696-1718, https://doi.org/10.1175/2009JCLI2909.1, 2010.

Wetter, O., Pfister, C., Werner, J. P., Zorita, E., Wagner, S., Seneviratne, S. I., Herget, J., Grünewald, U., Luterbacher, J., Alcoforado, M.-J., Barriendos, M., Bieber, U., Brázdil, R., Burmeister, K. H., Camenisch, C., Contino, A., Dobrovolný, P., Glaser, R., Himmelsbach, I., Kiss, A., Kotyza, O., Labbé, T., Limanówka, D., Litzenburger, L., Nordli, Ø., Pribyl, K., Retsö, D., Riemann, D., Rohr, C., Siegfried, W., Söderberg, J., and Spring, J.-L.: The year-long unprecedented European heat and drought of 1540 - a worst case, Clim. Change, 125, 349-363, https://doi.org/10.1007/s10584-014-1184-2, 2014.

Wilhite, D. A. and Pulwarty, R. S.: Drought as hazard: Understanding the natural and social context, in: Drought and Water Crises, edited by: Wilhite, D. A. and Pulwarty, R. S., Integrating Science, Management, and Policy, CRC Press, Taylor \& Francis Group, Boca Bayton, 3-20, 2018.

Yihdego, Y.: Drought and pest management, in: Management of Drought and Water Scarcity, edite by: Eslamian, S. and Eslamian, F., CRC Press, Boca Raton, 2018.

Zahradníček, P., Trnka, M., Brázdil, R., Možný, M., Štěpánek, P., Hlavinka, P., Žalud, Z., Malý, A., Semerádová, D., Dobrovolný, P., Dubrovský, M., and Řezníčková, L.: The extreme drought episode of August 2011-May 2012 in the Czech Republic, Int. 
J. Climatol., 35, 3335-3352, https://doi.org/10.1002/joc.4211, 2015.
Zhang, D. and Liang, Y.: A long lasting and extensive drought event over China in 1876-1878, Adv. Clim. Change Res., 1/2, 91-99, https://doi.org/10.3724/SP.J.1248.2010.00091, 2010. 